УДК $544.7773 .3+546.55 / 59$

\title{
MECHANISM OF ENHANCED OXIDATION ABILITY OF DILUTE NITRIC ACID AND DISSOLUTION OF PURE GOLD IN SEAWATER WITH NITRIC ACID
}

\begin{abstract}
M. Hojo
Department of Chemistry, Faculty of Science, Kochi University, Kochi, 780-8520, Japan

mhojo@kochi-u.ac.jp

https://orcid.org/0000-0001-7936-8104

It has been discovered that dilute nitric acid in reversed micelle systems can oxidize the $\mathrm{Br}^{-}$ion to $\mathrm{Br}_{2}$ and we have proposed that the nitryl (or nitronium) ion $\mathrm{NO}_{2}{ }^{+}$should be the active species in the oxidation process. Nitration of phenol in reversed micelle systems with dilute nitric acid, $\mathrm{CHCl}_{3} / \mathrm{CTAC} / \mathrm{H}_{2} \mathrm{O}\left(2.0 \mathrm{~mol} \mathrm{dm}^{-3}\right.$ $\mathrm{HNO}_{3}$ in the $1.0 \%(\mathrm{v} / \mathrm{v}) \mathrm{H}_{2} \mathrm{O}$ phase), has been performed at $35^{\circ} \mathrm{C}$ to obtain 2- and 4-nitrophenols, where CTAC represents cetyltrimethylammonium chloride. In aqueous $2.0 \mathrm{~mol} \mathrm{dm}^{-3} \mathrm{HNO}_{3}$ solution accompanied by $4.0 \mathrm{~mol} \mathrm{dm}^{-3} \mathrm{LiCl}$ (and a small amount of $\mathrm{LiBr}$ as the bromide resource), trans-1,4-dibromo-2-butene was successfully brominated to 1,2,3,4-tetrabromobutane. This result is good evidence that the $\mathrm{Br}^{-}$ion can be oxidized to $\mathrm{Br}_{2}$ in dilute nitric acid $\left(2.0 \mathrm{~mol} \mathrm{dm}^{-3}\right)$ providing it contains concentrated salts. For chloride salts, the cation effects increased as $\mathrm{Et}_{4} \mathrm{~N}^{+}<<\mathrm{Na}^{+}<\mathrm{Li}^{+}<\mathrm{Ca}^{2+}<\mathrm{Mg}^{2+}$. Even the evolution of $\mathrm{Cl}_{2}$ has been demonstrated from $<2.0 \mathrm{~mol} \mathrm{dm}{ }^{-3} \mathrm{HNO}_{3}$ solution containing concentrated $\mathrm{LiCl}, \mathrm{MgCl}_{2}$, and $\mathrm{CaCl}_{2}$ as well as $\mathrm{AlCl}_{3}$. The dissolution of precious metals ( $\mathrm{Au}, \mathrm{Pt}$, and $\mathrm{Pd}$ ), especially, of gold has been demonstrated in $0.1-2 \mathrm{~mol} \mathrm{dm}^{-3} \mathrm{HNO}_{3}$ accompanied by alkali metal, alkaline earth metal, and aluminum chlorides. The complete dissolution time of pure gold plate $(20 \pm 2 \mathrm{mg}, 0.1 \mathrm{~mm}$ thickness $)$ in $2.0 \mathrm{~mol} \mathrm{dm}{ }^{-3} \mathrm{HNO}_{3}$ accompanied by $1.0 \mathrm{~mol} \mathrm{dm}^{-3} \mathrm{AlCl}_{3}$ has been shortened remarkably with temperature increase from 15 to $80^{\circ} \mathrm{C}$. The dissolution rate constants, log $\left(\mathrm{k} / \mathrm{s}^{-1}\right)$, of a piece of gold wire $(19.7 \pm 0.5 \mathrm{mg})$ in $20 \mathrm{~mL}$ of $2.0 \mathrm{~mol} \mathrm{dm}^{-3} \mathrm{HNO}_{3}$ accompanied by the metal chlorides, in general, increase with increasing salt concentrations at 40 and $60^{\circ} \mathrm{C}$. The gold can be dissolved in the solution of $<1.0 \mathrm{~mol} \mathrm{dm}^{-3} \mathrm{HNO}_{3}$ and $<1.0 \mathrm{~mol} \mathrm{dm}^{-3} \mathrm{HCl}$, i.e. a "dilute aqua regia." We have achieved a total dissolution of five pieces of the gold wire (totally $0.10 \mathrm{~g}$ ) in $100 \mathrm{~mL}$ of the $1: 1$ mixture between seawater and $2.0 \mathrm{~mol} \mathrm{dm}^{-3} \mathrm{HNO}_{3}$ at ca. $100^{\circ} \mathrm{C}$.
\end{abstract}

Keywords: nitryl or nitronium ion, CTAC, evolution of chlorine, oxidation of bromide, salt effect, bulk water structure, dilute aqua regia, tetrachloroaurate, concentrated salt, Raman spectrum.

\section{Introduction}

Nitric acid has two different functions, a strong acid and a strong oxidizing agent in diluted and in concentrate conditions, respectively, and is one of the best known and most widely applied oxidizing agents in chemistry. Although the oxidation ability of $\mathrm{HNO}_{3}$ depends on its concentration in solution, it is common knowledge that dilute nitric acid has no oxidation ability. Airborne sea salt particles wet or dry can react with various gases, in particular various oxides of nitrogen, potentially contributing to the chemistry of the troposphere [1]. Cotton and Wilkinson [2] have described that nitric acid of $0.1 \mathrm{~mol} \mathrm{dm}^{-3}$ dissociates about $93 \%$ and that nitric acid of less than $2.0 \mathrm{~mol} \mathrm{dm}$ has virtually no oxidation ability. The dissociation constants of $\mathrm{HNO}_{3}$ at different concentration ranges in aqueous solution have been determined [3].

In a previous paper [4], however, we have reported that the $\mathrm{Br}^{-}$ion of the surfactant, $\mathrm{CTAB}$, is oxidized to $\mathrm{Br}_{2}$ (or $\mathrm{Br}_{3}{ }^{-}$) in the $\mathrm{CHCl}_{3} / \mathrm{CTAB} / \mathrm{H}_{2} \mathrm{O}$ reversed micelle system of $\mathrm{W}=1.0-4.0$ with dilute nitric acid $\left(0.25-2.5 \mathrm{~mol} \mathrm{dm}^{-3}\right.$ in the $1.0 \%(\mathrm{v} / \mathrm{v}) \mathrm{H}_{2} \mathrm{O}$ phase) at $15-40{ }^{\circ} \mathrm{C}$ where $\mathrm{CTAB}$ stands for cetyltrimethylammonium bromide and the $\mathrm{W}$ value is the ratio of $\left[\mathrm{H}_{2} \mathrm{O}\right] /[$ surfactant]. We proposed that the $\mathrm{NO}_{2}{ }^{+}$ion should be the active species in this oxidation process. Unfortunately, our proposal for the active species may not be recognized so much, regardless of our supplying reasonable evidence in the study. The changes in the hydrogen-bonding conditions of the water droplets in reversed micelle systems have been discussed on the basis of ${ }^{1} \mathrm{H}$ NMR chemical shifts [4]. The influence of salts, acids, and phenols on the hydrogen-bond structure of water-ethanol mixtures has been examined also by ${ }^{1} \mathrm{H}$ NMR spectroscopy [5].

For more than thirty years, we [6] have tried to demonstrate that alkali metal $\left(\mathrm{M}^{+}\right)$and alkaline earth metal $\left(\mathrm{M}^{2+}\right)$ ions have potentially the ability to coordinate with simple anions, such as $\mathrm{Cl}^{-}, \mathrm{NO}_{3}^{-}$, $\mathrm{RSO}_{3}^{-}, \mathrm{RCO}_{2}^{-}$, etc. Such minor interactions between $\mathrm{M}^{+}$or $\mathrm{M}^{2+}$ and simple anions could not be observed normally in dilute aqueous solution because of strong hydration toward both the metal cations 
and the anions. In poor solvating media such as acetonitrile, however, the chemical as well as Coulombic interaction between $\mathrm{M}^{+}$or $\mathrm{M}^{2+}$ and simple anions has been demonstrated by careful examination with electrochemical and spectroscopic techniques. Rather strong chemical interactions between alkaline earth metal ions and the benzoate ion in acetonitrile were found by UV-visible and NMR spectroscopy [7].

We have also proposed [6] that the properties of bulk water are based on the hydrogen-bond network among a huge number of $\mathrm{H}_{2} \mathrm{O}$ molecules (e.g., $\mathrm{n}_{\mathrm{w}}>\sim 10^{7}$ ). Water can lose its property as bulk water $(\mathrm{H}-\mathrm{O}-\mathrm{H})$ to get that of a non-aqueous solvent, such as an alcohol $(\mathrm{R}-\mathrm{O}-\mathrm{H})$ or even an ether (R-O-R) if the highly "self-assembled structure" of bulk water is destroyed in the following cases: (a) the residual water $\left(\mathrm{c}\left(\mathrm{H}_{2} \mathrm{O}\right) \sim 10^{-3} \mathrm{~mol} \mathrm{dm}^{-3}\right)$ in organic solvents; (b) aqueous solutions or organic solvent-water mixtures containing highly concentrated salts; (c) nanoscale water droplets in nano-tubes or reversed micelle systems; (d) water on metal electrodes, ion-exchange resins, proteins, organic solvents as the solvent extraction, and glass vessels; (e) water under supercritical conditions. Such waters can be "reduced" to the authentic singular $\mathrm{H}_{2} \mathrm{O}$ molecules (also called "dihydrogen ether", $(\mathrm{H})-\mathrm{O}-(\mathrm{H})$ ) [8]. Reichardt et al. [9] have concisely interpreted "dihydrogen ether" that, at high salt concentrations $\left(\mathrm{c}(\mathrm{salt})>5 \mathrm{~mol} \mathrm{dm}^{-3}\right)$, region $\mathrm{C}$, according to the solvation model of Frank and Wen [10], can be abolished and only regions A and B survive, resulting in an aqueous solvent called "dihydrogen ether".

Now, we would like to point out that hydrogen-bond dynamics of both water in highly concentrated $\mathrm{NaBr}$ solutions and in reversed micelle systems show a similar behavior [11]. In addition, Park et al. [11] have described that the water dynamics in $4 \mathrm{~nm}$ nano-pools in reversed micelle systems of both ionic and non-ionic surfactants is almost identical: confinement by an interface to form a nanoscopic water pool is the primary factor governing the dynamics of nanoscopic water rather than the presence of charged groups at the interface. Spectroscopic studies of the structure of surface water as it is affected by added salts, acids, and ammonia have been presented in a review article by Gopalakrishnan et al. [12]. The $\mathrm{OH}$ stretch of nitric acid in $\mathrm{CCl}_{4}$ has provided definitive proof of molecular nitric acid rather than $\mathrm{NO}_{3}^{-}[13]$.

With the assistance of above-mentioned two ideas, i.e., (1) chemical interaction between the metal cations and simple anions, (2) the change of water properties with the addition of concentrated salts and/or organic solvents, we have successfully explained the concentrated salt effects on solvolysis reactions of organic haloalkanes and related compounds without resorting to different types of ion pairs [8].

It is widely accepted that the $\mathrm{NO}_{2}{ }^{+}$ion is the active species in nitration reactions. March [14] has described in his textbook: "there is a great deal of evidence that $\mathrm{NO}_{2}{ }^{+}$is present in most nitration reactions and that it is the attacking entity".

In Part 1 of the present paper, a few examples for the nitration of phenols with dilute nitric acid $\left(2.0 \mathrm{~mol} \mathrm{dm}^{-3}\right)$ in various reversed micelle systems are reported. After that, we examine the oxidation of $\mathrm{Br}^{-}$to $\mathrm{Br}_{2}$ by dilute nitric acid in aqueous bulk solution containing concentrated salts in order to recognize that the $\mathrm{NO}_{2}{ }^{+}$ion can be produced within nanoscale water droplets in reversed micelle systems. In the course of our experiments, even the evolution of $\mathrm{Cl}_{2}$ as well as the oxidation of $\mathrm{Br}^{-}$to $\mathrm{Br}_{2}$ has been observed in dilute nitric acid in aqueous bulk solution containing concentrated salts. Finally, the distortion of bulk water structure is fully discussed for aqueous solutions containing concentrated salts, such as $\mathrm{LiCl}$ and $\mathrm{NaCl}$, based on experimental data observed with Raman and ${ }^{1} \mathrm{H}$ NMR spectroscopy.

In Part 2, pure gold dissolution in seawater mixed with aqueous nitric acid is demonstrated.

\section{Results and Discussion}

\section{Part 1 Formation of $\mathrm{NO}_{2}{ }^{+}$as the Intermediate in Reversed Micelle Systems and Bulk Aqueous Media from Dilute $\mathrm{HNO}_{3}$}

\subsection{Nitration of phenol with dilute nitric acid in $\mathrm{CHCl}_{3} / \mathrm{CTAC}$ reversed micelle}

First of all, we would like to characterize the reaction field in reversed micelle systems. Fig. 1 shows the change with time in the ${ }^{1} \mathrm{H}$ NMR chemical shift $(\delta)$ values of $\mathrm{OH}$ in water droplets $\left(1.0 \% \mathrm{H}_{2} \mathrm{O}\right.$ phase containing $\left.2.0 \mathrm{~mol} \mathrm{dm} \mathrm{HNO}_{3}\right)$ of reversed micelle systems, $\mathrm{CHCl}_{3} / \mathrm{CTAB} / \mathrm{H}_{2} \mathrm{O}$ $\left(\mathrm{W}=\left[\mathrm{H}_{2} \mathrm{O}\right] /[\right.$ surfactant $\left.]=2.0\right)$ and $\mathrm{CHCl}_{3} / \mathrm{CTAC} / \mathrm{H}_{2} \mathrm{O}(\mathrm{W}=4.0)$ at $25^{\circ} \mathrm{C}$. The $\delta\left({ }^{1} \mathrm{H}\right)$ value of the $\mathrm{CTAB}$ micelle system decreased after two hours with changing of the color from colorless to yellow, 
whereas that of the CTAC micelle system remained constant during five hours and even after 7 days. In the previous study [4], we have established that the oxidation of $\mathrm{Br}^{-}$ions to $\mathrm{Br}_{2}\left(\mathrm{Or} \mathrm{Br}_{3}{ }^{-}\right)$occurs with $0.25-2.0 \mathrm{~mol} \mathrm{dm}^{-3} \mathrm{HNO}_{3}$ (in the $1.0 \% \mathrm{H}_{2} \mathrm{O}$ phase) of the $\mathrm{CHCl}_{3} / \mathrm{CTAB} / \mathrm{H}_{2} \mathrm{O}(\mathrm{W}=2.0)$ reversed micelle system at $25^{\circ} \mathrm{C}$. We have also suggested that the oxidizing species should be the $\mathrm{NO}_{2}{ }^{+}$ion which is formed from the dilute nitric acid in the micelle system.

The decrease of the $\delta\left({ }^{1} \mathrm{H}\right)$ value in the CTAB micelle system has been attributed to the decrease in the nitric acid concentration, which should accompany the oxidation of $\mathrm{Br}^{-}$ions of the surfactant, CTAB. Contrastingly, it is obvious that $2.0 \mathrm{~mol} \mathrm{dm}^{-3} \mathrm{HNO}_{3}$ in the $\mathrm{CHCl}_{3} / \mathrm{CTAC} / \mathrm{H}_{2} \mathrm{O}(\mathrm{W}=4.0) \mathrm{mi}$ celle system could not oxidize the $\mathrm{Cl}^{-}$ions (of the surfactant, CTAC) into $\mathrm{Cl}_{2}$, thus, no decrease in the $\mathrm{HNO}_{3}$ concentration was observed. In brief conclusion, Eq. 1 can take place but not Eq. 2 in the two reversed micelle systems.

$$
\begin{aligned}
& 2 \mathrm{Br}^{-}+\mathrm{NO}_{2}^{+} \rightarrow \mathrm{Br}_{2}+\mathrm{NO}_{2}^{-} \\
& 2 \mathrm{Cl}^{-}+\mathrm{NO}_{2}^{+} \rightarrow \mathrm{Cl}_{2}+\mathrm{NO}_{2}^{-}
\end{aligned}
$$

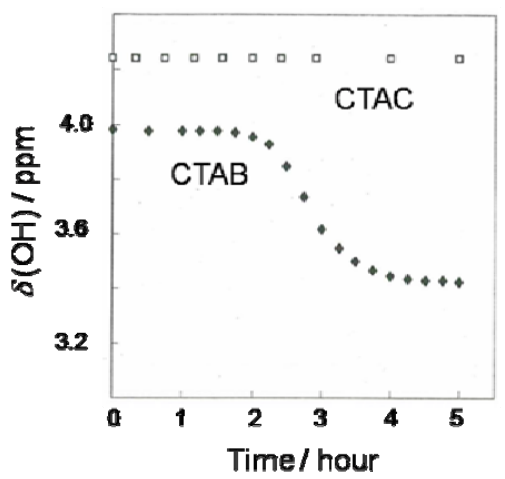

Figure 1. Time-dependent chemical shifts of $\delta(\mathrm{OH})$ in reversed micelle systems, $\mathrm{CHCl}_{3} / \mathrm{CTAB} / \mathrm{H}_{2} \mathrm{O}$ $(\mathrm{W}=2.0)$ and $\mathrm{CHCl}_{3} / \mathrm{CTAC} / \mathrm{H}_{2} \mathrm{O}(\mathrm{W}=4.0)$, containing $2.0 \mathrm{~mol} \mathrm{dm}^{-3} \mathrm{HNO}_{3}$ (in the $1.0 \% \mathrm{H}_{2} \mathrm{O}$ phase) at $25^{\circ} \mathrm{C}$.

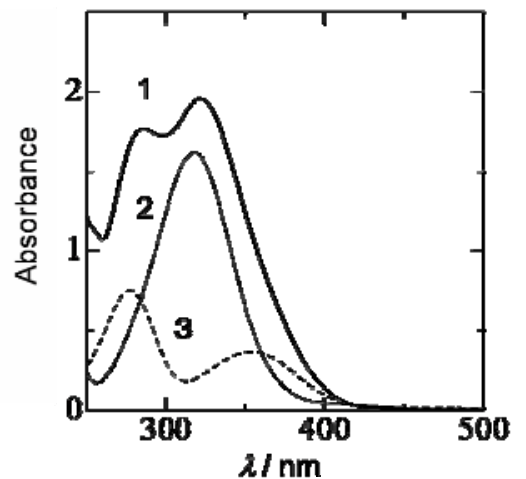

Figure 2. UV absorption spectra $(0.1 \mathrm{~cm}$ path-length) of the products from $2.5 \times 10^{-3} \mathrm{~mol} \mathrm{dm}^{-3}$ phenol formed in the reversed micelle system $\mathrm{CHCl}_{3} / \mathrm{CTAC} / \mathrm{H}_{2} \mathrm{O}$ $\left(\mathrm{W}=4.0\right.$ ), containing $2.0 \mathrm{~mol} \mathrm{dm}^{-3} \mathrm{HNO}_{3}$ (in the $1.0 \%$ $\mathrm{H}_{2} \mathrm{O}$ phase) at $35^{\circ} \mathrm{C}$ and the candidate compounds in the reversed micelle system: (1) products formed after four days; (2) $1.0 \times 10^{-3} \mathrm{~mol} \mathrm{dm}^{-3}$ 2-nitrophenol; (3) $1.0 \times 10^{-3} \mathrm{~mol} \mathrm{dm}{ }^{-3} 4$-nitrophenol.

Fig. 2 shows the UV spectrum based on the reaction products from $2.5 \times 10^{-3} \mathrm{~mol} \mathrm{dm}^{-3}$ phenol in the reversed micelle $\left(\mathrm{CHCl}_{3} / \mathrm{CTAC} / \mathrm{H}_{2} \mathrm{O}\right)$ at $\mathrm{W}=4.0$ containing $2.0 \mathrm{~mol} \mathrm{dm}^{-3} \mathrm{HNO}_{3}$ (in the $1.0 \% \mathrm{H}_{2} \mathrm{O}$ phase) after four days at $35^{\circ} \mathrm{C}$. Two bands at $\lambda_{\max }=285$ and $323 \mathrm{~nm}$ were observed. The UV spectrum of the reaction products was able to be fit with $1.6 \times 10^{-3} \mathrm{~mol} \mathrm{dm}^{-3}$ 2-nitrophenol and $1.4 \times 10^{-3} \mathrm{~mol}$ $\mathrm{dm}^{-3}$ 4-nitrophenol, that is, the ratio of (1.14):(1.00) for 2- and 4-nitrophenols with a reaction yield of $80 \%$ from phenol. This result seems to be reasonable since the OH-group of phenol has an ortho- and para-orientation tendency [15]. The production of 3-nitrophenol and 2,4-dinitrophenol was excluded based on their UV absorption spectra: reaction conditions are so gentle that 3-nitro- and dinitroderivatives were not produced.

\subsection{Nitration of 4-methylphenol with dilute nitric acid in CTAC and AOT reversed micelle systems}

Nitration of 4-methylphenol with dilute nitric acid was examined in the $\mathrm{CDCl}_{3} / \mathrm{CTAC} / \mathrm{H}_{2} \mathrm{O}$ reversed micelle system at $35{ }^{\circ} \mathrm{C}$. Fig. 3(a) shows the ${ }^{1} \mathrm{H}$ NMR spectrum of $0.010 \mathrm{~mol} \mathrm{dm}^{-3}$ 4-methylphenol in the reversed micelle $\left(\mathrm{CDCl}_{3} / \mathrm{CTAC} / \mathrm{H}_{2} \mathrm{O}\right)$ at $\mathrm{W}=8.0$ containing $2.0 \mathrm{~mol} \mathrm{dm}^{-3}$ $\mathrm{HNO}_{3}$ (in the $1.0 \% \mathrm{H}_{2} \mathrm{O}$ phase) just after solution preparation. Two doublet signals characterize the reactant 4-methylphenol. The ${ }^{1} \mathrm{H}$ NMR spectrum (for $\delta\left({ }^{1} \mathrm{H}\right)=5-10 \mathrm{ppm}$ ) of 4-methylphenol in the $\mathrm{CDCl}_{3} / \mathrm{CTAC} / \mathrm{H}_{2} \mathrm{O}$ reversed micelle system was almost identical with that of a commercial compound in $\mathrm{CDCl}_{3}$ solution. After completion of the reaction (two days later), the ${ }^{1} \mathrm{H}$ NMR signals shifted to the down-field direction; one singlet $(3 \mathrm{H})$ and two doublet signals $(5 \mathrm{H}$ and $6 \mathrm{H})$, shown in Fig. 3(b), indicated the formation of 2-nitro-4-methylphenol and the absence of the reactant 4-methylphenol. 


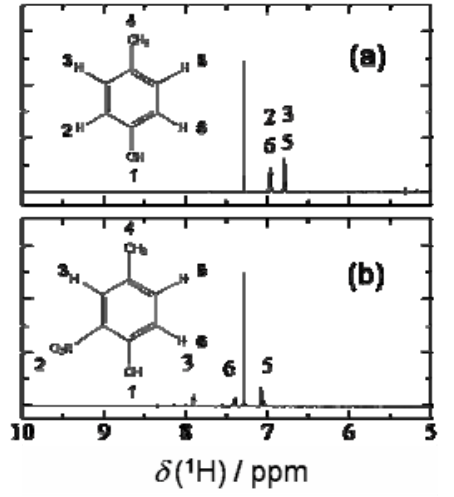

Figure 3. ${ }^{1} \mathrm{H}$ NMR spectra of (a) $0.01 \mathrm{~mol} \mathrm{dm}^{-3}$ 4-methylphenol in $\mathrm{CDCl}_{3} / \mathrm{CTAC} / \mathrm{H}_{2} \mathrm{O}(\mathrm{W}=4.0)$ reversed micelle in the presence of $2.0 \times 10^{-3} \mathrm{~mol} \mathrm{dm}^{-3}$ $\mathrm{HNO}_{3}$ (in the $1.0 \% \mathrm{H}_{2} \mathrm{O}$ phase) just after solution preparation and (b) the product formed from $0.01 \mathrm{~mol}$ $\mathrm{dm}^{-3}$ 4-methylphenol in the reversed micelle system after reaction completion (two days later at $35^{\circ} \mathrm{C}$ ).

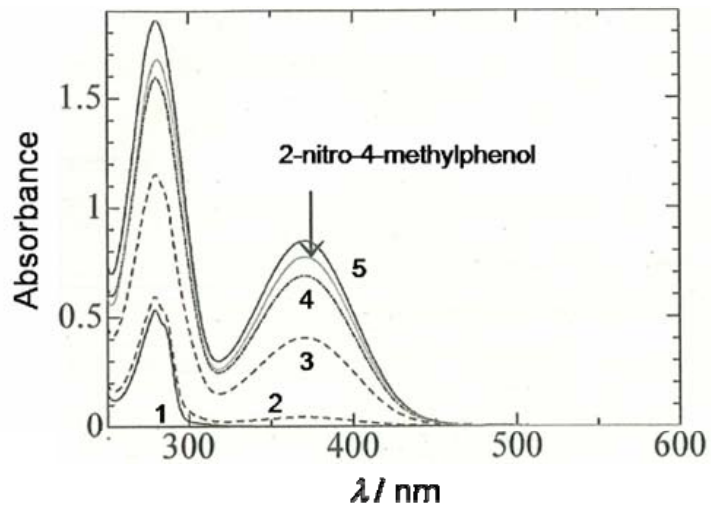

Figure 4. Changes of UV and visible spectra $(0.1 \mathrm{~cm}$ path-length) from $2.5 \times 10^{-3} \mathrm{~mol} \mathrm{dm}^{-3} 4$-methylphenol to 2-nitro-4-methylphenol with time in reversed micelle, $\mathrm{CHCl}_{3} / \mathrm{AOT} / \mathrm{H}_{2} \mathrm{O}(\mathrm{W}=2.0)$, containing $2.0 \mathrm{~mol} \mathrm{dm}^{-3}$ $\mathrm{HNO}_{3}$ (in the $1.0 \%$ water phase) at $35{ }^{\circ} \mathrm{C}$ : (1) 0 ; (2) 2.0 ; (3) 4.0 ; (4) 5.0 ; (5) $6.0 \mathrm{~h}$ later. Commercially obtained 2-nitro-4-methylphenol of $2.0 \times 10^{-3} \mathrm{~mol} \mathrm{dm}^{-3}$ is also displayed.

The reaction yield was evaluated by means of UV spectroscopy of 2-nitro-4-methylphenol from $2.5 \times 10^{-3} \mathrm{~mol} \mathrm{dm}{ }^{-3} 4$-methylphenol in the $\mathrm{CHCl}_{3} / \mathrm{CTAC} / \mathrm{H}_{2} \mathrm{O}$ reversed micelle system. The yield of the product increased with increasing $\mathrm{W}$ value, e.g. 88.5, 91.7, and $95.7 \%$ for $\mathrm{W}=1.2,2.0$, and 8.0, respectively, and the reaction time (for completion) was prolonged by smaller $\mathrm{W}$ values: 2,3 , and 5 days for $\mathrm{W}=2-8,1.5$, and 1.2 , respectively. One can expect some superiority in the yields and reaction rates for the smaller $\mathrm{W}$ values because of more remarkable distortion of the water structure. However, the experimental data indicates the opposite tendency. Similar opposite tendency have been reported for the oxidation of $\mathrm{Br}^{-}$in $\mathrm{CTAB}$ reversed micelle system [4].

The cationic surfactant, CATC, was then replaced by an anionic surfactant, AOT. Fig. 4 shows the formation of 2-nitro-4-methylphenol from $2.5 \times 10^{-3} \mathrm{~mol} \mathrm{dm}^{-3}$ 4-methylphenol in the reversed micelle $\left(\mathrm{CHCl}_{3} / \mathrm{AOT} / \mathrm{H}_{2} \mathrm{O}\right)$ at $\mathrm{W}=2.0$ containing $2.0 \mathrm{~mol} \mathrm{dm}^{-3} \mathrm{HNO}_{3}$ (in the $1.0 \% \mathrm{H}_{2} \mathrm{O}$ phase) at $35^{\circ} \mathrm{C}$. Two hours later, a reaction to some extent could be observed with a slight increase of absorbance at around $\lambda=280$ and $370 \mathrm{~nm}$. The reaction was completed after six hours to give a UV spectrum with two bands at $\lambda=281$ and $371 \mathrm{~nm}$ for 2-nitro-4-methylphenol with a reaction yield of $93.2 \%$. The influence of the $\mathrm{W}$ value on reaction time and yield was examined only for $\mathrm{W}=1.0-3.0$, since the reversed micelle system was unstable for $\mathrm{W}=4.0$ or more. Smaller $\mathrm{W}$ values caused slightly lower yields and longer reaction times: $92.1 \%(8 \mathrm{~h})$ and $94.0 \%(6 \mathrm{~h})$ for $\mathrm{W}=1.0$ and 3.0, respectively.

For the AOT system at $\mathrm{W}=2.0$, the replacement of $\mathrm{CHCl}_{3}$ with heptane as the organic phase caused the reaction rate of the nitration of 4-methylphenol to be much faster. The nitration reaction was completed in two hours with a yield of $98 \%$. At various $\mathrm{W}$ values $(\mathrm{W}=1.0-8.0)$, the yield and reaction time were obtained for 2-nitro-4-methylphenol from $2.5 \times 10^{-3} \mathrm{~mol} \mathrm{dm}^{-3} 4$-methylphenol in the reversed micelle (heptane/AOT/ $\mathrm{H}_{2} \mathrm{O}$ ) containing $2.0 \mathrm{~mol} \mathrm{dm}{ }^{-3} \mathrm{HNO}_{3}$ (in the $1.0 \% \mathrm{H}_{2} \mathrm{O}$ phase) at $35^{\circ} \mathrm{C}$. The reaction or completion time was always $2 \mathrm{~h}$, except for $\mathrm{W}=1.0(3.5 \mathrm{~h})$, and the yields were within $93-98 \%$. However, the insolubility of the CTAC surfactant in heptane prevented us from examining the reaction in a heptane $/ \mathrm{CTAC} / \mathrm{H}_{2} \mathrm{O}$ reversed micelle system.

Onori and Santucci [16] have investigated water structure in $\mathrm{CCl}_{4} / \mathrm{AOT} / \mathrm{H}_{2} \mathrm{O}$ reversed micelle systems. They have stated that the IR spectra can be expressed as sum of the contributions from interfacial and bulk-like water. Without doubt, the conditions in the nanoscale water droplets are quite different from that of intrinsic bulk water.

In $10 \mathrm{~mL}$ of heptane without surfactants, the nitration of $2.5 \times 10^{-3} \mathrm{~mol} \mathrm{dm}^{-3} 4$-methylphenol with $2.0 \mathrm{~mol} \mathrm{dm}{ }^{-3} \mathrm{HNO}_{3}(0.1 \mathrm{~mL})$ was examined at $35^{\circ} \mathrm{C}$. Turbidity was observed in heptane when sonication was performed for several minutes in order to mix the solvent and the small amount of dilute nitric acid. After one day at $35^{\circ} \mathrm{C}$, however, the solution became clear and the UV spectrum of the solution indicated the formation of 2-nitro-4-methylphenol of $93 \%$ yield. In this case, nitration took place in the absence of surfactants. In the review article of Gopalakrishnan et al. [12] they commented that 
infrared spectra of saturated solutions of water in $\mathrm{CCl}_{4}$ at room temperature can be assigned to water monomers or dimers. The water molecules mixed into heptane, including the turbidity particles, may exist in a variety of forms from the monomer to hydrogen-bonded oligomers, $\left(\mathrm{H}_{2} \mathrm{O}\right)_{n}$.

In $10 \mathrm{~mL}$ of $\mathrm{CHCl}_{3}$, on the other hand, 4-methylphenol could not be nitrated by $2.0 \mathrm{~mol} \mathrm{dm}^{-3} \mathrm{HNO}_{3}$ $(0.1 \mathrm{~mL})$ even after two weeks. Now, we would like to discuss briefly the reactivity (formation of $\mathrm{NO}_{2}{ }^{+}$as intermediate) in both solvents: the most obvious difference between two organic solvents must be in their acceptor numbers: $\sim 0$ and 23.1 for heptane and $\mathrm{CHCl}_{3}$, respectively [17], whereas the donor numbers of both solvents should be quite small $(\sim 0)$. Chloroform with the larger acceptor number (i.e., the larger basicity) can accept the hydrogen bond from the $\mathrm{H}$-atoms of nitric acid, which might cause a lower tendency to produce the $\mathrm{NO}_{2}{ }^{+}$ion.

Now, we wonder what kind of function surfactants may have for the reaction in reversed micelle systems. Additionally, the question is where the $\mathrm{NO}_{2}{ }^{+}$ion is generated, either within the aqueous phase or in the organic phase. In order to solve these problems, we examined the oxidation ability of dilute nitric acid in bulk water containing concentrated salts, as described in the following sections.

\subsection{Oxidation of $\mathrm{Br}^{-}$to $\mathrm{Br}_{2}$ with dilute nitric acid in aqueous bulk solution containing abundant salts}

Fig. 5 shows the UV-visible absorption spectra of a $2.0 \mathrm{~mol} \mathrm{dm}^{-3} \mathrm{HNO}_{3}$ aqueous solution, after addition of $4.0 \mathrm{~mol} \mathrm{dm}^{-3} \mathrm{LiCl}$ and $0.010 \mathrm{~mol} \mathrm{dm}^{-3} \mathrm{LiBr}$ at $35^{\circ} \mathrm{C}$. Note that the concentration of nitric acid is less than $2.0 \mathrm{~mol} \mathrm{dm}^{-3}$ (actually found to be $1.83 \mathrm{~mol} \mathrm{dm}^{-3}$ ) because a substantial part of the volumetric flask is occupied by a large amount of the salt, $\mathrm{LiCl}$, and only $2.0 \mathrm{~mol} \mathrm{dm}{ }^{-3} \mathrm{HNO}_{3}$ was handled for preparation of the solution. The solution turned soon from colorless to yellow. In the UV-visible spectra, a band of at around $371 \mathrm{~nm}$ developed gradually with time until 30 min passed. Commercially available $\mathrm{Br}_{2}$ gave $\mathrm{UV}$ absorption band at around $371 \mathrm{~nm}$ (absorptivity, $\mathrm{e} / \mathrm{cm}^{-1} \mathrm{~mol}^{-1} \mathrm{dm}^{3}=\mathrm{ca} .200$ ) in $4.0 \mathrm{~mol} \mathrm{dm}^{-3} \mathrm{LiCl}$ aqueous solution, cf., $\varepsilon=$ ca. 180 at $\lambda=390 \mathrm{~nm}$ in $2 \mathrm{~mol} \mathrm{dm}^{-3} \mathrm{HClO}_{4}$ [18]. Based on the absorptivity of $\mathrm{Br}_{2}$, the oxidation of the $\mathrm{Br}^{-}$ion $(\mathrm{LiBr})$ is suggested to be completed after $30 \mathrm{~min}$. The presence of $\mathrm{Br}_{2}$ in the concentrated salt solution (e.g., 4.0 or $5.0 \mathrm{~mol} \mathrm{dm}^{-3} \mathrm{LiCl}$ ) after the reaction was detected by the Rosaniline method [19]; the appearance of a red color $(1=\mathrm{ca} .570 \mathrm{~nm})$ proved the formation of $\mathrm{Br}_{2}$.
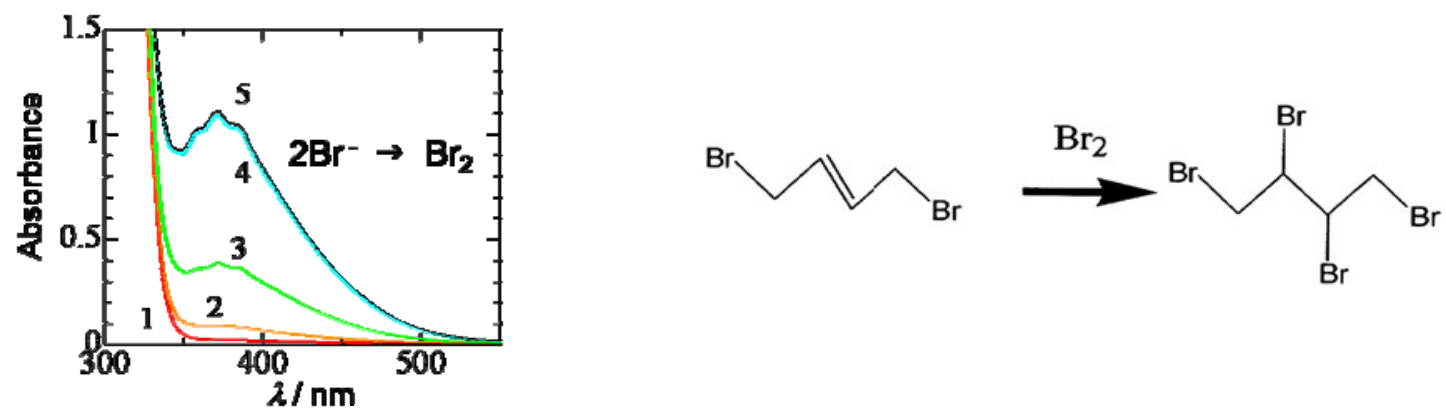

Figure 5. Formation of $\mathrm{Br}_{2}(1.0 \mathrm{~cm}$ path-length $)$ from $0.010 \mathrm{~mol} \mathrm{dm}^{-3} \mathrm{LiBr}$ in $2.0 \mathrm{~mol} \mathrm{dm}^{-3} \mathrm{HNO}_{3}$ solution,

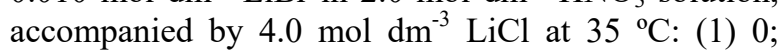

Scheme 1. The bromination of a butene to the butane. (2) 5 ; (3) 10 ; (4) 25 ; (5) 30 min later.

The formation of $\mathrm{Br}_{2}$ from $\mathrm{LiBr}$ with $2.0 \mathrm{~mol} \mathrm{dm}^{-3} \mathrm{HNO}_{3}$ accompanied by $4.0 \mathrm{~mol} \mathrm{dm}^{-3} \mathrm{LiCl}$ (and $0.010 \mathrm{~mol} \mathrm{dm}^{-3} \mathrm{LiBr}$ ) was confirmed also by means of ${ }^{1} \mathrm{H}$ NMR as follows: before and after the reaction, each solution of $10 \mathrm{~mL}$ in the presence of trans-1,4-dibromo-2-butene $\left(0.010 \mathrm{~mol} \mathrm{dm}^{-3}\right)$ was extracted with $2 \mathrm{~mL}$ of $\mathrm{CDCl}_{3}$. After the completion of reaction, the formation of 1,2,3,4-tetrabromobutane was demonstrated by the disappearance of a signal at $\delta\left({ }^{1} \mathrm{H}\right)=$ ca. $6.0 \mathrm{ppm}$ stemming from trans-1,4-dibromo-2-butene as well as the appearance of signals between $\delta\left({ }^{1} \mathrm{H}\right)=3.5-5.0 \mathrm{ppm}$. The formation of 1,2,3,4-tetrabromobutane from trans-1,4-dibromo-2-butene (cf. Scheme 1) is a good evidence for the oxidation of $\mathrm{Br}^{-}$with dilute nitric acid in the presence of $\mathrm{LiCl}$. It is true that the lithium ion has an advantage for getting good oxidation ability with dilute nitric acid, however, we would like to stress that $\mathrm{Li}^{+}$is not the essential ion component. At $35^{\circ} \mathrm{C}$, a solution of $2.0 \mathrm{~mol} \mathrm{dm}^{-3} \mathrm{HNO}_{3}$ accompanied by sodium chloride $\left(3.0 \mathrm{~mol} \mathrm{dm}^{-3}\right)$ and bromide $\left(0.010 \mathrm{~mol} \mathrm{dm}^{-3}\right)$, 
which contains no lithium ions, produced also $\mathrm{Br}_{2}$, though the reaction rate and the yield of $\mathrm{Br}_{2}$ (ca. $25 \%$ ) was low.

At various temperatures, examined were the time-dependent changes of absorbance at $1=\mathrm{ca}$. $371 \mathrm{~nm}$ of $\mathrm{Br}_{2}$ in $2.0 \mathrm{~mol} \mathrm{dm}^{-3} \mathrm{HNO}_{3}$ accompanied by $4.0 \mathrm{~mol} \mathrm{dm}{ }^{-3} \mathrm{LiCl}$ (and $0.010 \mathrm{~mol} \mathrm{dm}^{-3} \mathrm{LiBr}$ ). With increasing temperature, the reaction rate increases. The activation energy for $20-35{ }^{\circ} \mathrm{C}$ was evaluated to be $67.2 \mathrm{~kJ} \mathrm{~mol}^{-1}$ for the $4.0 \mathrm{~mol} \mathrm{dm}^{-3} \mathrm{LiCl}$ solution. With decreasing salt concentration, however, the reaction rate decreased remarkably; the activation energies were evaluated to be 58.6 and $45.0 \mathrm{~kJ} \mathrm{~mol}^{-1}$ for 3.7 and $3.5 \mathrm{~mol} \mathrm{dm}^{-3} \mathrm{LiCl}$. Naturally, with increasing $\mathrm{LiCl}$ concentration, the reaction rate increased. In $2.0 \mathrm{~mol} \mathrm{dm}^{-3} \mathrm{HNO}_{3}$ accompanied by $5.0 \mathrm{~mol} \mathrm{dm}^{-3} \mathrm{LiCl}$ (and $0.010 \mathrm{~mol} \mathrm{dm}^{-3} \mathrm{LiBr}$ ), the oxidation reaction proceeded too fast to evaluate the rate constant precisely, therefore, nitric acid of $1.0 \mathrm{~mol} \mathrm{dm}^{-3}$ was used for $5.0 \mathrm{~mol} \mathrm{dm}{ }^{-3} \mathrm{LiCl}$ to obtain $\log \left(\mathrm{k} / \mathrm{s}^{-1}\right)=-3.87$ at $25^{\circ} \mathrm{C}$.

In the case of $9.0 \mathrm{~mol} \mathrm{dm}^{-3} \mathrm{LiCl}$, at last, the nitric acid concentration was decreased down to $0.1 \mathrm{~mol} \mathrm{dm}^{-3}$ to get reasonable experimental conditions. In Table 1 are listed the apparent oxidationreaction rate constants, $\log \left(\mathrm{k} / \mathrm{s}^{-1}\right)$, for $0.10-2.0 \mathrm{~mol} \mathrm{dm}{ }^{-3}$ nitric acid accompanied by $\mathrm{LiCl}$ in high concentrations $\left(3.5-9.0 \mathrm{~mol} \mathrm{dm}^{-3}\right)$. It should be mentioned that the rate constants are not very precise values because the apparent molarity concentrations of nitric acid are always reduced by the volumes of a large amount of salts (vide supra); the actual molarity values are also listed in the table.

Table 1. The apparent rate constants, $\log \left(\mathrm{k} / \mathrm{s}^{-1}\right)$, ${ }^{\mathrm{a}}$ of formation of $\mathrm{Br}_{2}$ from dilute nitric acid (and $0.010 \mathrm{~mol} \mathrm{dm}^{-3}$ $\mathrm{LiBr}$ as the $\mathrm{Br}^{-}$resource) solution containing alkali metal and alkaline earth metal chlorides at $20-40^{\circ} \mathrm{C}$.

\begin{tabular}{|c|c|c|c|c|c|c|}
\hline $\mathrm{salt}_{\mathrm{mol} \mathrm{dm}}$ & $\mathrm{HNO}_{3} / \mathrm{mol} \mathrm{dm}^{-3}$ & $40^{\circ} \mathrm{C}$ & $35^{\circ} \mathrm{C}$ & $30^{\circ} \mathrm{C}$ & $25^{\circ} \mathrm{C}$ & $20^{\circ} \mathrm{C}$ \\
\hline $\mathrm{LiCl}, 4.0$ & $2.0^{\mathrm{b}}(1.83)^{\mathrm{c}}$ & & -2.57 & -2.76 & -2.96 & -3.24 \\
$\mathrm{LiCl}, 5.0$ & $1.0(0.894)$ & & -3.23 & -3.63 & -3.87 & -4.13 \\
$\mathrm{LiCl}, 6.5$ & $0.5(0.431)$ & & -3.36 & -3.72 & -3.94 & -4.22 \\
$\mathrm{LiCl}, 8.0$ & $0.2(0.167)$ & -3.70 & -3.80 & -4.03 & & \\
$\mathrm{LiCl}, 9.0$ & $0.1(0.081)$ & -3.87 & -3.97 & -4.20 & & \\
$\mathrm{NaCl}, 3.5$ & $2.0(1.84)$ & & -4.81 & -5.19 & -5.43 & \\
$\mathrm{MgCl}_{2}, 1.7$ & $2.0(1.60)$ & & & -2.51 & -3.14 & -3.49 \\
$\mathrm{CaCl}_{2}, 2.5$ & $2.0(1.83)$ & & -2.68 & -2.93 & -3.47 & -3.51 \\
\hline
\end{tabular}

${ }^{a}$ Evaluated from the slope of $\ln \left(\mathrm{A}_{\infty}-\mathrm{A}_{\mathrm{t}}\right)$ vs. t, where $\mathrm{A}_{\infty}$ and $\mathrm{A}_{\mathrm{t}}$ represent the absorbance at reaction completion and at each time, respectively.

${ }^{\mathrm{b}}$ The concentration of $\mathrm{HNO}_{3}$ solution, with which the salt was dissolved.

c The actual $\mathrm{HNO}_{3}$ concentration in the reaction flask, evaluated by the weight and the total volume values.

All the $\log \left(\mathrm{k} / \mathrm{s}^{-1}\right)$ values observed are between ca. -4.0 to ca. -2.5 at $25-35^{\circ} \mathrm{C}$, in other words, the reaction rates were adjusted by controlling the concentrations of both $\mathrm{HNO}_{3}$ and $\mathrm{LiCl}$ for obtaining appropriate experimental data. In the case of sodium chloride, 3.5 and not $4.0 \mathrm{~mol} \mathrm{dm}^{-3}$ salt solution was utilized because of the smaller solubility of $\mathrm{NaCl}$ in $2.0 \mathrm{~mol} \mathrm{dm} \mathrm{HNO}_{3}$. A $2.0 \mathrm{~mol} \mathrm{dm}^{-3} \mathrm{HNO}_{3}$ aqueous solution accompanied by $3.5 \mathrm{~mol} \mathrm{dm}^{-3} \mathrm{NaCl}$ (and $0.010 \mathrm{~mol} \mathrm{dm}^{-3} \mathrm{LiBr}$ ) at $25^{\circ} \mathrm{C}$ gave the $\log$ $\left(\mathrm{k} / \mathrm{s}^{-1}\right)$ value of -5.43 and this value is much smaller than that $(-3.75)$ for $3.5 \mathrm{~mol} \mathrm{dm}^{-3} \mathrm{LiCl}$. Note that the actual concentration of " $2.0 \mathrm{~mol} \mathrm{dm}^{-3} \mathrm{HNO}_{3}$ ", accompanied by $3.5 \mathrm{~mol} \mathrm{dm}{ }^{-3} \mathrm{LiCl}$ or $\mathrm{NaCl}$ were found to be each $1.84 \mathrm{~mol} \mathrm{dm}^{-3}$. The large difference in the $\log \left(\mathrm{k} / \mathrm{s}^{-1}\right)$ values between $\mathrm{LiCl}$ and $\mathrm{NaCl}$ is probably caused not only by some interaction between $\mathrm{M}^{+}$and $\mathrm{NO}_{3}{ }^{-}$but also by the change of the water structure through hydrogen bonding in the presence of these salts. In the final section of Part 1, the water structure through hydrogen bonding will be discussed based on the Raman and ${ }^{1} \mathrm{H}$ NMR spectral data of $\mathrm{D}_{2} \mathrm{O}$ or $\mathrm{H}_{2} \mathrm{O}$ containing $\mathrm{LiCl}, \mathrm{NaCl}$, and other salts.

As for non-metallic salts, a $2.0 \mathrm{~mol} \mathrm{dm}^{-3} \mathrm{HNO}_{3}$ solution accompanied by $3.5 \mathrm{~mol} \mathrm{dm}^{-3} \mathrm{Et}_{4} \mathrm{NCl}$ (and $0.010 \mathrm{~mol} \mathrm{dm}{ }^{-3} \mathrm{LiBr}$ ) at 30 and $35^{\circ} \mathrm{C}$ gave no $\mathrm{Br}_{2}$ even $50 \mathrm{~h}$ later, although we have observed the pro-

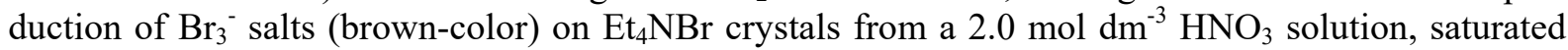
with $\mathrm{Et}_{4} \mathrm{NBr}$ after several days at room temperature. It is obvious that the metal ions play an important role in the oxidation process with dilute nitric acid. Magnesium and calcium chlorides promoted remarkably the oxidation reaction with dilute nitric acid: it was necessary for us to employ lower concentrations for these salts to obtain appropriate experimental data. The $\log \left(\mathrm{k} / \mathrm{s}^{-1}\right)$ values for $\mathrm{MgCl}_{2}$ and $\mathrm{CaCl}_{2}$ are also listed in Table 1. The effects by alkali metal and alkaline earth metal chlorides were 
classified as $\mathrm{Et}_{4} \mathrm{NCl}<<\mathrm{NaCl}<\mathrm{LiCl}<\mathrm{CaCl}_{2}<\mathrm{MgCl}_{2}$. This order of cations is just similar to that of the cation effect on solvolysis reaction rates of $\mathrm{S}_{\mathrm{N}} 1$ substrates [8].

After examining the heterogeneous reactions of oxides of nitrogen with $\mathrm{NaCl}$ as a model for sea salt particles, Langer et al. [1] inferred that $\mathrm{NaCl}$ may not be the component of sea salt which is most reactive with $\mathrm{HNO}_{3}$. Rossi [20] has summarized the study by Langer et al. [1] in a review article, "this study indicates that $\mathrm{HNO}_{3}$ and $\mathrm{NO}_{2}$ appear to react preferentially with hydrate salts such as $\mathrm{MgCl}_{2} \cdot 6 \mathrm{H}_{2} \mathrm{O}$, which is one of the constituents of natural sea salt". Admitting that they studied in heterogeneous phases, our observation is consistent with the result obtained by them [1].

\subsection{Evolution of $\mathrm{Cl}_{2}$ in concentrated chloride salt solutions and mechanism of the oxidation of the $\mathrm{Br}^{-}$ion}

In $2.0 \mathrm{~mol} \mathrm{dm}^{-3} \mathrm{HNO}_{3}$ accompanied by $1.0 \mathrm{~mol} \mathrm{dm}^{-3} \mathrm{AlCl}_{3}$ (and $0.010 \mathrm{~mol} \mathrm{dm}^{-3} \mathrm{LiBr}$ ) at $20-35^{\circ} \mathrm{C}$, the reaction proceeded quickly to give $\mathrm{Br}_{2}$ but yields were not so high. In addition, we noticed that $\mathrm{Cl}_{2}$ gas seemed to be produced from the solution. Therefore, the $\mathrm{Cl}_{2}$ formation was examined by the o-tolidine method [21] for $2.0 \mathrm{~mol} \mathrm{dm}^{-3} \mathrm{HNO}_{3}$ accompanied by $1.0 \mathrm{~mol} \mathrm{dm}^{-3} \mathrm{AlCl}_{3}$ at room temperature. Chlorine was detected by the absorption band at $\lambda=437.5 \mathrm{~nm}$ in the test solutions, sampled from the vapor phase as well as from the condense phase (the $\mathrm{HNO}_{3}$ solution). By the same method, the formation of $\mathrm{Cl}_{2}$ was demonstrated in $2.0 \mathrm{~mol} \mathrm{dm}{ }^{-3} \mathrm{HNO}_{3}$ accompanied by $\mathrm{LiCl}, \mathrm{MgCl}_{2}$, and $\mathrm{CaCl}_{2}$ of $4.0,1.7$, and $2.5 \mathrm{~mol} \mathrm{dm}$, respectively. Although we failed to determine $\mathrm{Cl}_{2}$ from $2.0 \mathrm{~mol} \mathrm{dm}^{-3} \mathrm{HNO}_{3}$ accompanied by $3.5 \mathrm{~mol} \mathrm{dm}^{-3} \mathrm{NaCl}$ in a preliminary experiment, we believe that the formation of $\mathrm{Cl}_{2}$ is possible from all the (dilute) nitric acid solutions containing concentrated chloride salts which we have examined.

The standard redox potentials, $\mathrm{E}^{\mathrm{o}}$, of $\mathrm{NO}_{2}{ }^{+} / \mathrm{NO}_{2}{ }^{\circ}$ and $\mathrm{NO}_{2}{ }^{+} / \mathrm{N}_{2} \mathrm{O}_{4}$ are reported to be 1.35 and $1.50 \mathrm{~V}$ [22], respectively, cf. $\mathrm{E}^{\mathrm{o}}=1.396 \mathrm{~V}$ for $\mathrm{Cl}_{2}(a q)+2 e^{-} \rightarrow 2 \mathrm{Cl}^{-}(a q)$ [23]. Olah [24] has described that the reversible potential for reduction of $\mathrm{NO}_{2}{ }^{+}$in acetonitrile is $1.45 \mathrm{~V}$ (vs. NHE), citing an electrochemical paper [25]. The oxidation of $\mathrm{Cl}^{-}$to $\mathrm{Cl}_{2}$ with $\mathrm{NO}_{2}{ }^{+}$must be possible according to the redox potentials of $\mathrm{NO}_{2}^{+}$and $\mathrm{Cl}_{2}$.

Behnke et al. [26] have stated that $\mathrm{NO}_{2}{ }^{+}$reacts with water to form $2 \mathrm{H}^{+}$and $\mathrm{NO}_{3}{ }^{-}$or with $\mathrm{Cl}^{-}$to produce nitryl chloride $\left(\mathrm{ClNO}_{2}\right)$ in their atmospheric chemical experiment of $\mathrm{N}_{2} \mathrm{O}_{5}$ on liquid $\mathrm{NaCl}$ aerosols or bulk $\mathrm{NaCl}$ solution at $291 \mathrm{~K}$. However, it is known that [27] nitryl chloride is soluble in water and it decomposes to nitric and hydrochloric acids. The mixture (aqua regia) of concentrate $\mathrm{HNO}_{3}$ and $\mathrm{HCl}$ is ready to evolve $\mathrm{Cl}_{2}$ and nitrosyl chloride ( $\mathrm{NOCl}$ ) [28]. Coincidentally, nitration of a calixarene compound by anhydrous $\mathrm{AlCl}_{3}$ and $\mathrm{KNO}_{3}$ in $\mathrm{CH}_{2} \mathrm{Cl}_{2}$ has been reported [29]. Another aluminum salt, $\mathrm{Al}\left(\mathrm{H}_{2} \mathrm{PO}_{4}\right)_{3}$, serves as an efficient solid acid catalyst of nitration of a variety of organic substances with $70 \%$ nitric acid [30].

Having the evolution of $\mathrm{Cl}_{2}$ is demonstrated, the oxidation mechanism of the $\mathrm{Br}^{-}$to $\mathrm{Br}_{2}$ should be reconsidered. The oxidation of the $\mathrm{Br}^{-}$ion of $\mathrm{LiBr}$ in concentrated $\mathrm{LiCl}$ solution can occur not only directly by $\mathrm{NO}_{2}{ }^{+}$but also indirectly through $\mathrm{Cl}_{2}$, as expressed by Eqs. 2 and 3:

$$
2 \mathrm{Br}^{-}+\mathrm{Cl}_{2} \rightarrow \mathrm{Br}_{2}+2 \mathrm{Cl}^{-}
$$

The reaction given in Eq. 3 was inferred from the formation profile of $\mathrm{Br}_{2}$ in the dilute nitric acid containing chloride salts, that is, the absorbance of $\mathrm{Br}_{2}$ increased gradually from the beginning of reaction time. On the other hand, the formation profile of $\mathrm{Br}_{2}$ in dilute nitric acid containing non-chloride salts is completely different from that of chloride salts. Fig. 6 shows the change of $\mathrm{Br}_{2}$ concentration with time in $2.0 \mathrm{~mol} \mathrm{dm}^{-3} \mathrm{HNO}_{3}$ (and $0.010 \mathrm{~mol} \mathrm{dm} \mathrm{diBr}^{-3}$ ) accompanied by lithium trifluoromethanesulfonate, perchlorate, and nitrate salts. The absorbance of $\mathrm{Br}_{2}$ increased not from the initial time but after an induction period for each salt. The oxidation reaction of other non-chloride lithium and sodium salts, such as $\mathrm{CH}_{3} \mathrm{SO}_{3} \mathrm{Na}$ or $\mathrm{NaHSO}_{4}$, also need a long induction period before the formation of $\mathrm{Br}_{2}$ starts. The details of the influence of cation and anion components on the generation of $\mathrm{NO}_{2}{ }^{+}$as the active species from dilute nitric acid will be reported later. We just mention that the basicities of anions from salts in higher concentrations may influence on the generation of $\mathrm{NO}_{2}{ }^{+}$from dilute $\mathrm{HNO}_{3}$. Kinetics and mechanism of the autocatalytic oxidation with nitric acid have been reviewed by Bazsa [31].

\subsection{Distortion of bulk water structure in the presence of concentrated $\mathrm{LiCl}$ and $\mathrm{NaCl}$}

According to Frank and Wen [10], $\mathrm{Li}^{+}$and $\mathrm{Cs}^{+}$ions in aqueous solution are regarded to be structure making and breaking, respectively. This classification for cations or salts is widely accepted in solu- 
tion chemistry. However, we would like to point out that this argument must be limited to lower salt concentrations in solution. In the presence of salts in high concentrations (e.g., $5 \mathrm{~mol} \mathrm{dm}^{-3}$ ), bulk water molecules are consumed for hydrating the ions, therefore, the bulk water part (properly structured with an enormous number of water molecules) in solution is reduced or even disappears and only isolated water molecules should be left for solvating foreign chemical species [6].

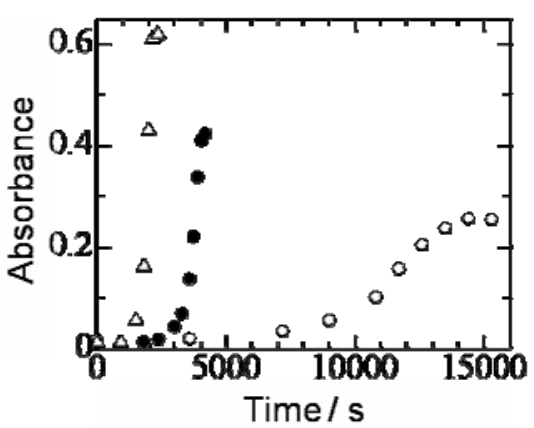

Figure 6. Time-dependent absorbance $(1.0 \mathrm{~cm}$ path-length) at around $1=371 \mathrm{~nm}$ of a $2.0 \mathrm{~mol} \mathrm{dm}{ }^{-3} \mathrm{HNO}_{3}$ solution, accompanied by $3.5 \mathrm{~mol} \mathrm{dm}^{-3}$ lithium salts (and $0.010 \mathrm{~mol} \mathrm{dm}^{-3}$ $\mathrm{LiBr})$ at $35{ }^{\circ} \mathrm{C}:(\triangle) \mathrm{CF}_{3} \mathrm{SO}_{3} \mathrm{Li} ;(\bullet) \mathrm{LiClO}_{4}$; (०) $\mathrm{LiNO}_{3}$.

Fig. 7 shows the changes of Raman spectra of $\mathrm{D}_{2} \mathrm{O}$ with changing $\mathrm{R}$ values of $\mathrm{LiCl}$ and $\mathrm{NaCl}$ where $\mathrm{R}=\left[\mathrm{D}_{2} \mathrm{O}\right] /$ [salt]. Excitation for the Raman spectroscopy was provided by a $514.5 \mathrm{~nm}$ argon laser. The two peaks at ca. 2390 and $2500 \mathrm{~cm}^{-1}$ of $\mathrm{D}_{2} \mathrm{O}$ in the absence of salts can be attributed to O-D stretching bands of strongly and weakly hydrogen-bonded $\mathrm{D}_{2} \mathrm{O}$ molecules, respectively [8c-8e,32]. With decreasing $\mathrm{R}$ values (i.e., with increasing salt concentration), the intensity of the band of weakly hydrogen-bonded water increases at the expense of that of strongly hydrogen-bonded water for both $\mathrm{LiCl}$ and $\mathrm{NaCl}$ solutions. The Raman spectra obviously indicate that the water structure through hydrogen-bonding is much destroyed in concentrated $\mathrm{LiCl}$ as well as $\mathrm{NaCl}$ solution. Furthermore, examining the distortion of the water structure, we found, $\mathrm{LiCl}$ has a stronger impact than $\mathrm{NaCl}$. At $\mathrm{R}=20$, for instance, the ratio of Raman intensities $\left(\mathrm{I}_{2} / \mathrm{I}_{1}\right)$ is 0.64 and 0.72 for $\mathrm{LiCl}$ and $\mathrm{NaCl}$, respectively, where $\mathrm{I}_{1}$ and $\mathrm{I}_{2}$ represent Raman intensities at ca. 2500 and $2390 \mathrm{~cm}^{-1}$. The smaller Raman ratio for the $\mathrm{D}_{2} \mathrm{O}$ solution of $\mathrm{LiCl}$, as compared with that of $\mathrm{NaCl}$, indicates that the water structure is more distorted by $\mathrm{LiCl}$, rather than $\mathrm{NaCl}$ of the same molality concentration: $\mathrm{R}$ value of 20 corresponds to $2.5 \mathrm{~mol} \mathrm{~kg}^{-1}$.

Coincidently, Pastroczak et al. [33] have demonstrated how the intensity ratio of two main band components of $\mathrm{H}_{2} \mathrm{O}$ (around 3200 and $3400 \mathrm{~cm}^{-1}$ ) depends on the excitation laser wavelength in the visible range. Note that the ratio $\left(\mathrm{I}_{2} / \mathrm{I}_{1}\right)$ is 1.08 for pure $\mathrm{D}_{2} \mathrm{O}$ and that $\mathrm{D}_{2} \mathrm{O}$ is somewhat more structured than $\mathrm{H}_{2} \mathrm{O}\left(\mathrm{I}_{2} / \mathrm{I}_{1}=0.90\right.$ for 3250 and $3400 \mathrm{~cm}^{-1}$, laser excitation at $\left.514.5 \mathrm{~cm}^{-1}\right)$. Gordon [34] has already mentioned that $\mathrm{D}_{2} \mathrm{O}$ is a more structured liquid than $\mathrm{H}_{2} \mathrm{O}$.

\subsection{Integration of apparent contradiction between NMR and Raman spectroscopy}

Now, we have to declare that ${ }^{1} \mathrm{H}$ NMR chemical shifts of $\mathrm{H}_{2} \mathrm{O}$ containing the salts were found to be apparently controversy to the Raman results. Fig. 8 shows the $\Delta \delta$ values changed by various cations or anions of $1.0 \mathrm{~mol} \mathrm{dm}{ }^{-3}$ in $2.0 \%(\mathrm{v} / \mathrm{v})$ EtOH- $\mathrm{H}_{2} \mathrm{O}$ solution. We have found that these $\Delta \delta$ values observed in $2.0 \%$ are not so much different from those observed in $20 \%(\mathrm{v} / \mathrm{v}) \mathrm{EtOH}-\mathrm{H}_{2} \mathrm{O}$ solution, previously reported [5]. We can notice that the difference of the $\Delta \delta$ values between $\mathrm{Mg}^{2+}$ and $\mathrm{Ca}^{2+}$ are definitely smaller than that observed in $20 \%(\mathrm{v} / \mathrm{v}) \mathrm{EtOH}-\mathrm{H}_{2} \mathrm{O}$ solution, though.

The separation of the effects by the anion and cation components in a salt was performed according to Hindman's method [35] $\left(\Delta \delta\left(\mathrm{NH}_{4}{ }^{+}\right)=0\right)$ : the details of the procedure have been described previously [5]. Magnesium, calcium, and lithium ions having smaller ionic sizes $(\mathrm{r} / \mathrm{z})$ gave positive $\Delta \delta$ values while $\mathrm{Na}^{+}, \mathrm{K}^{+}, \mathrm{Rb}^{+}$, and $\mathrm{Cs}^{+}$gave negative values; where $\mathrm{r}$ and $\mathrm{z}$ are the crystal ion radius and the 
number of charges, respectively. Positive and negative $\Delta \delta$ values should be correspondent to structure making and breaking, respectively. Based on the ${ }^{1} \mathrm{H}$ NMR data, $\mathrm{Li}^{+}$is structure making while $\mathrm{Na}^{+}$and $\mathrm{Cl}^{-}$are structure braking. Thus, the ${ }^{1} \mathrm{H}$ NMR data for these ions are in good accordance with the model of Frank and Wen [10].

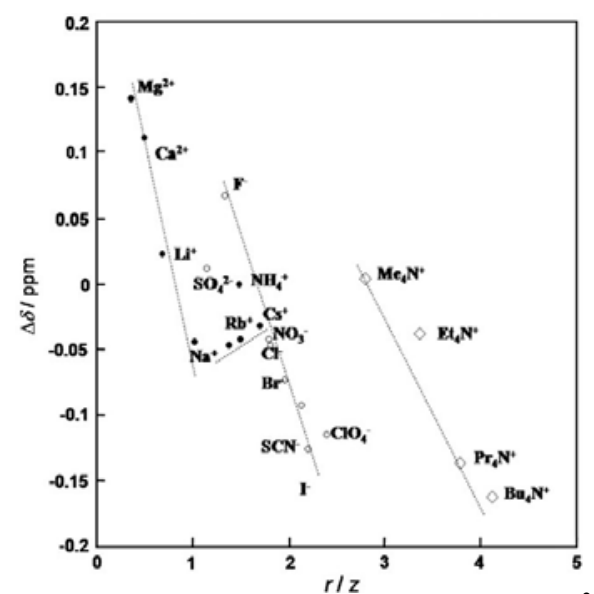

Figure 8. The $\Delta \delta$ values vs. $\mathrm{r} / \mathrm{z}$ for various cations and anions at $1.0 \mathrm{~mol} \mathrm{dm}{ }^{-3}$ in $2.0 \%(\mathrm{v} / \mathrm{v}) \mathrm{EtOH}-\mathrm{H}_{2} \mathrm{O}$ solution, where $\mathrm{r}$ and $\mathrm{z}$ are the crystal ion radius and the number of charge, respectively. The signal of the methyl group in EtOH served as the internal standard for the chemical shift.

As discussed above, however, the Raman spectra supply us with the information that the water structure is more distorted by higher concentration of $\mathrm{LiCl}$ than of $\mathrm{NaCl}$. Such an apparent contradiction between Raman and NMR data has been one of the most difficult points to clear in solution chemistry. Now we suppose that ${ }^{1} \mathrm{H}$ NMR system may reflect the ion hydration (neighboring part of ions) even though the bulk water is almost lost in the presence of salts in higher concentrations, whereas Raman spectroscopy seems to be able to evaluate the degree how much an aqueous solution is changed from the initial bulk water as the result of adding salts. Note that the condition of water structure around a metal ion (e.g., $\mathrm{Li}^{+}$or $\mathrm{Fe}^{2+}$ ), developed by its ionic field or coordination ability, must be quite different from that of the bulk water. Raman spectra may distinguish the difference between hydration and bulk water molecules but NMR spectra may not. As mentioned above, we have proposed of change in the properties of bulk water into those of "dihydrogen ether" [8] in the presence of highly concentrated salts. It is, indeed, necessary for us to arrange slightly the idea of Frank and Wen [10] (structure-making or breaking ions) in order to account for the controversy feature between Raman and ${ }^{1} \mathrm{H}$ NMR spectroscopy.

The influence of $\mathrm{MgCl}_{2}$ and $\mathrm{CaCl}_{2}$ on the water structure has been examined by means of ${ }^{17} \mathrm{O} \mathrm{NMR}$ and Raman spectroscopy [36]. Changes in Raman spectra indicated the break of the fully hydrogen bonded water structure with increasing concentration of $\mathrm{MgCl}_{2}$ and $\mathrm{CaCl}_{2}$. However, the $\delta\left({ }^{17} \mathrm{OH}_{2}\right)$ values increased (down-field shift) with increasing concentration of $\mathrm{MgCl}_{2}$ and $\mathrm{CaCl}_{2}$. The authors have described that results from ${ }^{17} \mathrm{O}$ NMR and Raman measurements are "compatible" with each other. Obviously, in the truth, they have had encountered the contradiction just similar to ours. However, they evaded the difficult situation by describing, "though $\mathrm{CaCl}_{2}$ and $\mathrm{MgCl}_{2}$ destroy four hydrogen-bonded water structures, they promote the water structure in the mass".

Yonehama et al. [37] reported the O-D stretching frequency in aqueous electrolyte solutions. Although they paid their precise attention only to the frequency changes but not to the intensities in Raman spectra, they cast a most important comment as follows: the term "structure-making and structure-breaking" is a confusing expression in that incorporation of small ions in water invites a new structure (hydration structure) formation different from the intrinsic water structure.

\section{Part 2 Pure gold dissolution in seawater mixed with aqueous nitric acid}

In an editorial article [38] is written that "many people have the impression that gold occurs as nuggets in streambeds and being a noble metal is only dissolved by aqua regia, mixture of concentrated hydrochloric and nitric acids". Beckham et al. [39] described that Geber, an Arabian chemist, mentioned aqua regia in the eighth century. In the metallurgy of gold, many leaching (dissolution in 
liquids) methods were known [40]. Chlorine-Chloride leaching was applied commercially in the $19^{\text {th }}$ century, but its use diminished following the introduction of the cyanide process in 1887 .

The redox potentials [23] for gold species are as follows:

$$
\begin{aligned}
\mathrm{Au}^{+}+e^{-} \rightarrow & \mathrm{Au}, E^{0}=1.83 \mathrm{~V} \text { and } \mathrm{Au}^{3+}+3 e^{-} \rightarrow \mathrm{Au}, E^{0}=1.52 \mathrm{~V} \\
& \mathrm{AuCl}_{2}^{-}+e^{-} \rightarrow \mathrm{Au}+2 \mathrm{Cl}^{-}, E^{0}=1.154 \mathrm{~V} \\
& \mathrm{AuCl}_{4}^{-}+3 e^{-} \rightarrow \mathrm{Au}+4 \mathrm{Cl}^{-}, E^{0}=1.002 \mathrm{~V}
\end{aligned}
$$

The comparison between Eqs. 4 and 5 indicates that the Au(III) complex is more stable than the $\mathrm{Au}(\mathrm{I})$ species by $0.15 \mathrm{~V}$. Oxidation will occur only above approximately, $1.2 \mathrm{~V}$, and therefore a strong oxidant, such as $\mathrm{Cl}_{2}$ or $\mathrm{O}_{3}$, is required to dissolve gold at a reasonable rate [41]. The redox potential of $\mathrm{Cl}_{2}(\mathrm{~g})$ to $\mathrm{Cl}^{-}(\mathrm{aq})$ is reported to be $1.358 \mathrm{~V}$ [41] and that of $\mathrm{O}_{3}$ to $\mathrm{O}_{2}$ to be $2.075 \mathrm{~V}$ or $1.246 \mathrm{~V}$ in acidic or basic solution, respectively [41].

We have recognized that the nitronium ion $\left(\mathrm{NO}_{2}{ }^{+}\right)$, the active species for nitration or oxidation, can be generated not only in the water phase of reversed micellar systems but also in bulk water containing salts in higher concentrations. Eq. 6 is the common reaction scheme to produce $\mathrm{NO}_{2}{ }^{+}$in concentrate nitric acid and we have assumed that the same scheme can be applied to even the diluted nitric acid in reversed-micellar water droplets [4] as well as in bulk water containing higher concentrations of salts.

$$
2 \mathrm{HNO}_{3} \rightarrow \mathrm{NO}_{2}^{+}+\mathrm{NO}_{3}^{-}+\mathrm{H}_{2} \mathrm{O}
$$

With an intimate examination of Eq. 6, we may notice that enhanced formation of $\mathrm{HNO}_{3}$ in its molecular state and not dissociated $\left(\mathrm{H}^{+}+\mathrm{NO}_{3}{ }^{-}\right)$is essential for a favorite $\mathrm{NO}_{2}^{+}$generation. In bulk aqueous solution, however, many people may be suspicious that diluted nitric acid is apt to dissociate completely. How could we keep the nitric acid molecules from dissociating to protons and nitrate ions? Reducing the solvent's permittivity (e.g. $\varepsilon_{\mathrm{r}}<10$ ) may be an excellent way for that purpose. However, the permittivity of bulk aqueous solutions cannot be reduced so well. Then, our idea, the alternation of $\mathrm{H}_{2} \mathrm{O}$ into "dihydrogen ether"[8], could resolve some of the problems. Both the "strong" acidity and basicity of water are lost at once when the water molecules in the huge network are broken into isolated molecules by some of the causes already mentioned, such as, the abundant addition of salts and increased temperature. For solutions with very high salt concentrations, we may not rely so much on the Debye-Hückel [42] and Pitzer [43] theories, even though being highly developed, because such new or extraordinary phenomena have not been predicted in advance by calculations making use of these theories, at least at the moment. We have already mentioned that the redox potential of $\mathrm{NO}_{2}{ }^{+}$ generated in diluted nitric acid should be high enough to oxidize $\mathrm{Cl}^{-}$into $\mathrm{Cl}_{2}$.

The present adventure, that is, dissolving gold in aqueous nitric acid, has been initiated not by any coincidence but by our reasoned deduction. As described above, dilute nitric acid in bulk water, provided it contains salts in high concentrations, can oxidize the $\mathrm{Cl}^{-}$ion to $\mathrm{Cl}_{2}$. Therefore, it is an inevitable theory that the evolved $\mathrm{Cl}_{2}$ should oxidize $\mathrm{Au}^{0}$ into $\mathrm{Au}^{3+}$, which is, at the same time, coordinated by the abundant $\mathrm{Cl}^{-}$ions, when the aqueous nitric acid is accompanied by sufficient amounts of chloride salts.

In Part 2, we would like to demonstrate the dissolution of precious metals ( $\mathrm{Au}, \mathrm{Pt}$, and $\mathrm{Pd}$ ), and to give detailed reports on gold dissolution in aqueous nitric acid $\left(<2 \mathrm{~mol} \mathrm{dm}^{-3}\right)$ containing alkali metal, alkaline earth metal, and aluminum chlorides at $15-100{ }^{\circ} \mathrm{C}$.

\subsection{Total dissolution of pure gold in 2 mol dm $m^{-3}$ aqueous $\mathrm{HNO}_{3}$ solution containing concentrated salts}

The gold dissolution has been examined with gold plate. Fig. 9 shows the period (time in hour) needed for the complete dissolution of a piece of gold plate $(20 \pm 2 \mathrm{mg}$, the thickness of $0.1 \mathrm{~mm})$ in a $20 \mathrm{~mL}$ solution of $2.0 \mathrm{~mol} \mathrm{dm}^{-3} \mathrm{HNO}_{3}$, accompanied by $1.0 \mathrm{~mol} \mathrm{dm}^{-3} \mathrm{AlCl}_{3}$, at various temperatures. It takes a long time, ca. 35 hours at $15^{\circ} \mathrm{C}$, however, the dissolution period was shortened with increasing temperature, e.g. less than 30 minutes at 70 or $80{ }^{\circ} \mathrm{C}$. The aqueous $\mathrm{HNO}_{3}$ solution acquires the increased dissolution ability with the temperature increase.

Next, the gold dissolution into the aqueous $\mathrm{HNO}_{3}$ solution has been examined with the gold wire instead of the gold plate. Fig. 10 shows the time for complete dissolution of a piece of gold wire $(19.7 \pm 0.5 \mathrm{mg}$, diameter of $0.25 \mathrm{~mm})$ in a $20 \mathrm{~mL}$ solution of $2.0 \mathrm{~mol} \mathrm{dm}{ }^{-3} \mathrm{HNO}_{3}$, accompanied by various chloride salts, at $60{ }^{\circ} \mathrm{C}$. With increasing salt concentrations (from $1.0 \mathrm{~mol} \mathrm{dm}{ }^{-3}$ ), generally speaking, the complete dissolution time is shortened. However, an interesting reversal trend is observed for 
more than $5.0 \mathrm{~mol} \mathrm{dm}{ }^{-3} \mathrm{LiCl}$ : the gold dissolution in a $2 \mathrm{~mol} \mathrm{dm}^{-3} \mathrm{HNO}_{3}$ solution needs longer time in the presence of 7.0 or 9.0 than $5.0 \mathrm{~mol} \mathrm{dm}{ }^{-3} \mathrm{LiCl}$. The most remarkable reversal effect is exhibited by $\mathrm{CaCl}_{2}$. The dissolution time reaches its minimum at around $2.5 \mathrm{~mol} \mathrm{dm}^{-3} \mathrm{CaCl}_{2}$ and get longer again after reaching a concentration of $3.0 \mathrm{~mol}$ of the salt.

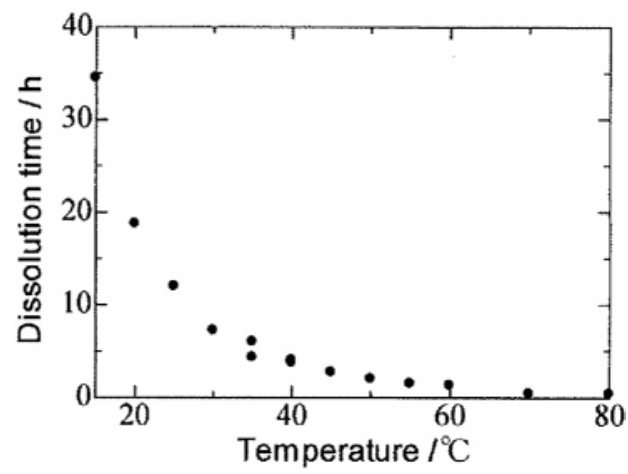

Figure 9. Time for the complete dissolution of gold plate $(20 \pm 2 \mathrm{mg})$ in $2.0 \mathrm{~mol} \mathrm{dm}{ }^{-3} \mathrm{HNO}_{3}$, accompanied by $1.0 \mathrm{~mol} \mathrm{dm}^{-3} \mathrm{AlCl}_{3}$ at various temperatures.

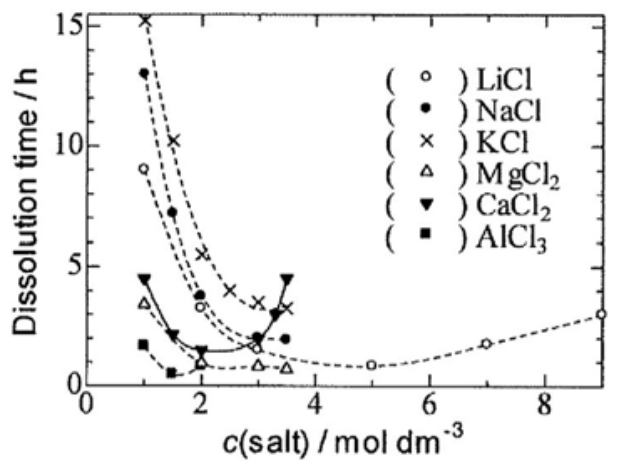

Figure 10. Time for the complete dissolution of gold wire $(19.7 \pm 0.5 \mathrm{mg})$ in $2.0 \mathrm{~mol} \mathrm{dm}{ }^{-3} \mathrm{HNO}_{3}$, accompanied by various chloride salts at $60^{\circ} \mathrm{C}$.

As to dissolving gold, $\mathrm{MgCl}_{2}$ is more effective than $\mathrm{CaCl}_{2}$. The influence of metal chlorides (at $1.0 \mathrm{~mol} \mathrm{dm}^{-3}$ ) for the rate of gold dissolution increases in the order $\mathrm{KCl}<\mathrm{NaCl}<\mathrm{LiCl}<\mathrm{CaCl}_{2}<$ $\mathrm{MgCl}_{2}<\mathrm{AlCl}_{3}$. At a lower temperature, $40^{\circ} \mathrm{C}$, much longer time is needed for complete dissolution of the gold wire in a $20 \mathrm{~mL}$ solution of $2.0 \mathrm{~mol} \mathrm{dm}^{-3} \mathrm{HNO}_{3}$ than at $60^{\circ} \mathrm{C}$. For instance, it takes 13 hours for the solution with $3.0 \mathrm{~mol} \mathrm{dm}{ }^{-3} \mathrm{NaCl}$ at $40{ }^{\circ} \mathrm{C}$, but only 2 hours at $60^{\circ} \mathrm{C}$. In any case, all the results obtained with the metal chlorides at $40{ }^{\circ} \mathrm{C}$ were very similar to those observed at $60{ }^{\circ} \mathrm{C}$. We would like to mention that the complete dissolution experiments of the gold wire in the solutions of much lower $\mathrm{HNO}_{3}$ (down to $0.1 \mathrm{~mol} \mathrm{dm}^{-3}$ ) concentrations containing the chloride salts have been also successfully performed at $60^{\circ} \mathrm{C}$.

The dissolution capacity for $\mathrm{Au}$ has been examined as follows: a $2 \mathrm{~mL}$ solution of $2.0 \mathrm{~mol} \mathrm{\textrm {dm } ^ { - 3 }}$ $\mathrm{HNO}_{3}$ is poured to $0.57 \mathrm{~g}$ of $\mathrm{MgCl}_{2}\left(\mathrm{ca} .3 \mathrm{~mol} \mathrm{dm}^{-3}\right)$ in a small beaker, and gold wire of $0.10 \mathrm{~g}$ is put in the solution. The beaker is placed on a hot-plate at ca. $80^{\circ} \mathrm{C}$, the gold wire dissolved completely in 40 minutes: the capacity can be estimated to be $50 \mathrm{~g} \mathrm{Au} / \mathrm{L}$ of $2 \mathrm{~mol} \mathrm{dm}^{-3} \mathrm{HNO}_{3}$, accompanied by $3 \mathrm{~mol} \mathrm{dm}^{-3} \mathrm{MgCl}_{2}$. On the other hand, it takes several days for a $0.040 \mathrm{~g} \mathrm{Pt}$ wire $(0.1 \mathrm{~mm}$ diameter $)$ to be dissolved in $10 \mathrm{~mL}$ of $2 \mathrm{~mol} \mathrm{dm}^{-3} \mathrm{HNO}_{3}$, accompanied by $3 \mathrm{~mol} \mathrm{dm}^{-3} \mathrm{MgCl}_{2}$ at $80^{\circ} \mathrm{C}$, giving a $\mathrm{Pt}$ capacity of at least $4 \mathrm{~g} \mathrm{Pt} / \mathrm{L}$. We will also note that $\mathrm{Pd}$ can be dissolved in a 1:1 mixture between $2.0 \mathrm{~mol} \mathrm{dm}^{-3} \mathrm{HNO}_{3}$ and seawater (vide infra).

For other precious metals, Ir and $\mathrm{Ru}$, dissolution experiments have been performed. However, these metals (in powder) are not dissolved in $2 \mathrm{~mol} \mathrm{dm}^{-3} \mathrm{HNO}_{3}$, accompanied by $3 \mathrm{~mol} \mathrm{dm} \mathrm{MgCl}_{2}$. It is well known that both Ir and $\mathrm{Ru}$ are not dissolved even in proper aqua regia [44]. Our method for dissolving precious metals (such as $\mathrm{Au}, \mathrm{Pt}$, or Pd) has a similar but weaker function than normal aqua regia. However, we would like to stress that our method has a higher efficiency of chemicals, without useless evolution of $\mathrm{NO}$ and $\mathrm{Cl}_{2}$ during gold dissolution in regular aqua regia.

\subsection{Dissolution rate constants and cation effects}

The UV-visible spectroscopy has been employed to identify the dissolved species formed from the gold wire. Fig. 11 shows the changes with time in the absorption spectra (in $0.1 \mathrm{~cm}$ path-length) of a $2.0 \mathrm{~mol} \mathrm{dm}{ }^{-3} \mathrm{HNO}_{3}$ solution containing a piece of gold wire $(\mathrm{ca} .19 .7 \mathrm{mg}$ ) in the presence of $3.5 \mathrm{~mol}$ $\mathrm{dm}^{-3} \mathrm{NaCl}$. A band appears and increases with time, which is accompanied by a peak at $\lambda \sim 306 \mathrm{~nm}$ and a shoulder around $400 \mathrm{~nm}$, while the initial $\mathrm{HNO}_{3}$ gives a band at $\lambda \sim 300 \mathrm{~nm}$. The spectrum observed after 12 hours in a $0.05 \mathrm{~cm}$ cuvette is consistent to that of $5.0 \times 10^{-3} \mathrm{~mol} \mathrm{dm}^{-3} \mathrm{NaAuCl}_{4}$ dissolved in a $2.0 \mathrm{~mol} \mathrm{dm}^{-3} \mathrm{HNO}_{3}$ solution. Therefore, we can safely conclude that the species dissolved in the $2 \mathrm{~mol} \mathrm{dm}^{-3} \mathrm{HNO}_{3}$ and $3.5 \mathrm{~mol} \mathrm{dm}^{-3} \mathrm{NaCl}$ solution is definitely the $\mathrm{AuCl}_{4}{ }^{-}$ion. Jones et al. [45] have reported the single crystal X-ray structure of $\mathrm{Mg}\left[\mathrm{Au}(\mathrm{OH})_{4}\right]_{2}$ and $\mathrm{Ca}\left[\mathrm{Au}(\mathrm{OH})_{4}\right]_{2}$, which have been obtained from reactions between $\mathrm{HAuCl}_{4}$ and $\mathrm{Ca}(\mathrm{OH})_{2}$. 
Beckham et al.[39] noted that, when nitric acid is mixed with solid sodium chloride, there are formed sodium nitride, chlorine, and nitrosyl chloride: $3 \mathrm{NaCl}+4 \mathrm{HNO}_{3} \rightarrow 3 \mathrm{NaNO}_{3}+\mathrm{Cl}_{2}+\mathrm{NOCl}+$ $2 \mathrm{H}_{2} \mathrm{O}$. They mentioned that "the system is similar to aqua regia." Concentrated $\mathrm{NOCl}$ in solution, such as aqua regia, should give a more dark orange or reddish color. The UV-visible absorption crosssections of $\mathrm{NOCl}$ have been reported [46].

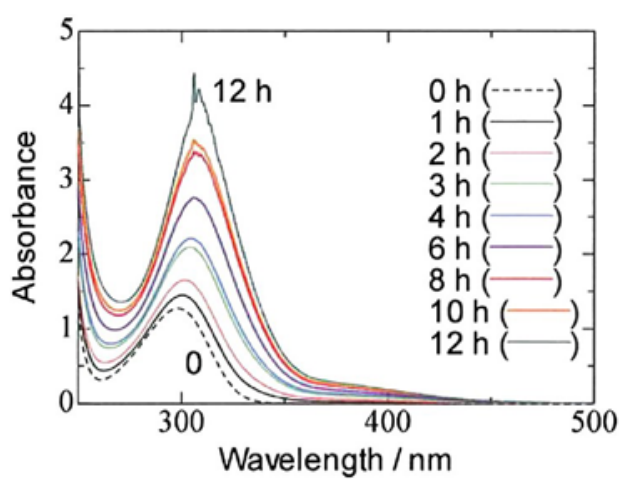

Figure 11. Changes in the UV-vis absorption spectra with time of $\mathrm{AuCl}_{4}^{-}$in $2.0 \mathrm{~mol} \mathrm{dm}^{-3} \mathrm{HNO}_{3}$ containing $3.5 \mathrm{~mol} \mathrm{dm}{ }^{-3} \mathrm{NaCl}$ at $40{ }^{\circ} \mathrm{C}$.

The dissolution reaction rate constants (the first-order reaction) have been evaluated with the changes in the solid gold mass as well as the absorbance at $\lambda \sim 375 \mathrm{~nm}$, for avoiding the rather large $\mathrm{HNO}_{3}$ absorbance (at $\lambda \sim 300 \mathrm{~nm}$ ). We have adopted the linear part of the plots of $\ln [\mathrm{S}] \mathrm{vs}$. t, since the plots tend to deviate from the linearity downward (i.e., reaction accelerated) after the half-life period. It should be mentioned that the rate constant is for the initial dissolution process and that effects of the surface area on the reaction rate can be minimized by taking the values obtained with the initial part of each experiment.

Table 2. The gold dissolution rate constant, $\log \left(\mathrm{k} / \mathrm{s}^{-1}\right)$, measured in $2.0 \mathrm{~mol} \mathrm{dm}{ }^{-3} \mathrm{HNO}_{3}$, accompanied by various added chloride salts at $40^{\circ} \mathrm{C}$.

\begin{tabular}{cccccc}
\hline $\mathrm{c}(\mathrm{salt}) / \mathrm{mol} \mathrm{dm}^{-3}$ & $\mathrm{LiCl}$ & $\mathrm{NaCl}$ & $\mathrm{MgCl}_{2}$ & $\mathrm{CaCl}_{2}$ & $\mathrm{AlCl}_{3}$ \\
\hline \multirow{2}{*}{0.5} & & & & & $-4.67^{\mathrm{a}}$ \\
1.0 & & & & & $-4.63^{\mathrm{b}}$ \\
& & & -4.49 & -4.59 & -4.00 \\
1.5 & & & -4.48 & -4.57 & -3.97 \\
& & & -4.09 & & -3.61 \\
2.0 & -4.39 & -4.62 & -3.82 & -4.09 & \\
& -4.37 & -4.69 & & -4.06 & \\
3.0 & -4.10 & -4.29 & -3.51 & -3.99 & \\
& -4.03 & -4.27 & & & \\
3.5 & & -4.21 & -3.54 & -4.26 & \\
& & -4.27 & & & \\
4.0 & -3.84 & & & & \\
5.0 & -3.84 & & & & \\
6.0 & -3.59 & & & & \\
\hline
\end{tabular}

${ }^{a}$ The $\left(k / s^{-1}\right)$ values in the upper rows are evaluated from the loss of the gold mass, $\ln \left(M_{t} / M_{0}\right)$ vs. $t / s$ where $M_{0}$ and $\mathrm{M}_{\mathrm{t}}$ are the gold masses at the initial and a certain time, respectively.

${ }^{b}$ The $\left(k / s^{-1}\right)$ values in the lower rows are evaluated from the absorbance values at $375 \mathrm{~nm}, \ln \left(\mathrm{A}_{\infty}-\mathrm{A}_{\mathrm{t}}\right) \mathrm{vs}$. $\mathrm{t} / \mathrm{s}$ where $\mathrm{A}_{\infty}$ and $\mathrm{A}_{t}$ are absorbance values after the complete gold dissolution and at a certain time, respectively.

In general, rate constants obtained by the different two ways are consistent to each other (cf. Table 2). However, the results from the absorbance method can be fluctuated, especially, when the concentrations of the chloride ion are quite high; in such cases, the solution turns already to a yellow color 
before placing gold. For its simplicity, we may take the rate constants obtained by the loss of the gold mass, except for some cases in which the mass method could not be appropriately applied. In the present paper, the rate constants evaluated by the mass method are given, unless otherwise noted.

\subsection{Gold dissolution into seawater and the seawater assisted by added chloride salts}

Seawater is an electrolyte solution. Its chemistry is dominated by the presence of six ions $\mathrm{Na}^{+}, \mathrm{K}^{+}$, $\mathrm{Mg}^{2+}, \mathrm{Ca}^{2+}, \mathrm{Cl}^{-}, \mathrm{SO}_{4}{ }^{2-}$ ) which constitute more than $99.5 \%$ of the dissolved constituents [47]. The concentrations of the main components have been reported to be $0.468,0.010,0.053,0.010,0.545$, and $0.028 \mathrm{~mol} \mathrm{~kg}^{-1}$, respectively, for the $35 \%$ seawater [48]. Taking into account its density $(\mathrm{d}=1.025$ as the average)[49], we can regard the seawater as a $0.55 \sim 0.56 \mathrm{~mol} \mathrm{dm}^{-3}$ chloride solution with mainly sodium and partly magnesium cations.

All experimental results in the present work strongly suggest that pure gold should dissolve in seawater if it is mixed with aqueous nitric acid and then heated. We have utilized "Muroto Deep Seawater" as a standard sample of seawater. The main components in the seawater are well consistent with the typical $35 \%$ seawater. By mixing $50 \mathrm{~mL}$ seawater with $50 \mathrm{~mL}$ of $2.0 \mathrm{~mol} \mathrm{dm}^{-3} \mathrm{HNO}_{3}$, we have a $100 \mathrm{~mL}$ solution of $1.0 \mathrm{~mol} \mathrm{dm}{ }^{-3} \mathrm{HNO}_{3}$ containing $0.278 \mathrm{~mol} \mathrm{dm}^{-3} \mathrm{Cl}^{-}, 0.225 \mathrm{~mol} \mathrm{dm}^{-3} \mathrm{Na}^{+}$, $0.026 \mathrm{~mol} \mathrm{dm}^{-3} \mathrm{Mg}^{2+}\left(0.014 \mathrm{~mol} \mathrm{dm}{ }^{-3} \mathrm{SO}_{4}{ }^{2-}\right)$ and other ions. The mixed solution is heated up to ca. $100{ }^{\circ} \mathrm{C}$ in a flask, equipped with a condenser. When boiling starts, then five pieces of gold wire (totally $0.10 \mathrm{~g}$ ) are placed into the solution. Occasionally, samplings are carried out from the boiling solution and the pieces of gold wire are dissolved completely within 17 hours. The absorbance values at $1=375 \mathrm{~nm}$ are utilized for evaluating the dissolution rate constant to give $\log \left(\mathrm{k} / \mathrm{s}^{-1}\right)=-4.52$. Another Pacific seawater off Hawaii (1,000 m depth) gives a value (-4.54) similar to that of "Muroto Deep Seawater". Although ten pieces of gold wire (totally ca. $0.20 \mathrm{~g}$ ) have appeared to dissolve completely in the $100 \mathrm{~mL}$ (seawater and nitric acid mixture) solution, after cooling down, some residue is noticed on the solution surface. Therefore, we keep five pieces $(0.10 \mathrm{~g})$ of gold wire as the limit for the seawater experiments. Incidentally, platinum is too tough to be dissolved in the seawater and $2.0 \mathrm{~mol} \mathrm{dm}^{-3}$ $\mathrm{HNO}_{3}(1: 1)$ mixture even after 10 days at ca. $100{ }^{\circ} \mathrm{C}$. However, within 24 hours, a piece of Pd wire $(0.04 \mathrm{~g}, 0.25 \mathrm{~mm}$ diameter, $99.9 \%)$ has dissolved in a $50 \mathrm{~mL}$ mixed (1:1) solution between the seawater and $2.0 \mathrm{~mol} \mathrm{dm}{ }^{-3} \mathrm{HNO}_{3}$ at ca. $100^{\circ} \mathrm{C}$.

Fig. 12 shows the increasing dissolution rate constant with increasing $\mathrm{NaCl}$ added to the seawater. The solution preparation procedure is as follows: The seawater is poured to $11.69 \mathrm{~g} \mathrm{NaCl}$ crystals up to $50 \mathrm{~mL}$ in a volumetric flask to prepare an additional $4.0 \mathrm{~mol} \mathrm{dm}^{-3} \mathrm{NaCl}$ seawater solution. Mixing between $50 \mathrm{~mL}$ of $2.0 \mathrm{~mol} \mathrm{dm}^{-3} \mathrm{HNO}_{3}$ and $50 \mathrm{~mL}$ of the additional $4.0 \mathrm{~mol} \mathrm{dm}^{-3} \mathrm{NaCl}$ seawater solution gives $100 \mathrm{~mL}$ of $1.0 \mathrm{~mol} \mathrm{dm}^{-3} \mathrm{HNO}_{3}$ containing additional $2.0 \mathrm{~mol} \mathrm{dm}^{-3} \mathrm{NaCl}$ seawater solution (totally ca. $2.23 \mathrm{~mol} \mathrm{dm}^{-3} \mathrm{Na}^{+}$and ca. $2.28 \mathrm{~mol} \mathrm{dm}^{-3} \mathrm{Cl}^{-}$).

The $\log \left(\mathrm{k}^{-1} \mathrm{~s}^{-1}\right)$ value increases remarkably from -4.52 to -3.71 with additional $0.5 \mathrm{~mol} \mathrm{dm} \mathrm{dm}^{-3} \mathrm{NaCl}$ and it remains almost a constant value up to $2.0 \mathrm{~mol} \mathrm{dm}^{-3} \mathrm{NaCl}$. As for platinum, however, a $2.8 \mathrm{mg} \mathrm{Pt}$ mass has been left without dissolving out of ca. $20 \mathrm{mg}$ platinum wire $(0.1 \mathrm{~mm}$ diameter $)$ in $100 \mathrm{~mL}$ of the $1.0 \mathrm{~mol} \mathrm{dm}^{-3} \mathrm{HNO}_{3}$ and $0.5 \mathrm{~mol} \mathrm{dm}^{-3} \mathrm{NaCl}$ added seawater after six days. Without the support by additional salts, however, no Pt can be dissolved in the 1:1 mixture between seawater and $2.0 \mathrm{~mol} \mathrm{dm}^{-3}$ $\mathrm{HNO}_{3}$ (vide supra).

We just mention that the "excellent" dissolution ability of seawater mixed with $2.0 \mathrm{~mol} \mathrm{dm}{ }^{-3} \mathrm{HNO}_{3}$ for gold has been successfully applied to collecting of gold from waste electronic devises, just mechanically tipped. The ICP-atomic emission spectrometry has demonstrated the dissolution of Au out of the waste electronic devices, as well as $\mathrm{Cu}, \mathrm{Ni}, \mathrm{Al}, \mathrm{Si}, \mathrm{Zn}$, and $\mathrm{B}$. Recovery of gold from secondary sources has been widely reviewed by S. Syed [50].

\section{4 "Dilute aqua regia" of various $\mathrm{HNO}_{3}$ and $\mathrm{HCl}$ concentrations}

In the CRC book [51] the preparation procedure of aqua regia is described as follows: "Mix 1 part concentrated $\mathrm{HNO}_{3}$ with 3 parts of concentrated $\mathrm{HCl}$. This formula should include one volume of water if the aqua regia is to be stored for any length of time. Without water, objectionable quantities of chlorine and other gases are evolved". According to this description, it has been well known that dilution with water is essential for the long term storage of active aqua regia. Assuming $16 \mathrm{~mol} \mathrm{dm}^{-3}$ $\mathrm{HNO}_{3}(70 \%)$ and $12 \mathrm{~mol} \mathrm{dm}-3 \mathrm{HCl}$, the original aqua regia is composed of $4 \mathrm{~mol} \mathrm{dm} \mathrm{HNO}_{3}$ and 
$9 \mathrm{~mol} \mathrm{dm}{ }^{-3} \mathrm{HCl}$, while the water added solution is calculated to contain still $3.2 \mathrm{~mol} \mathrm{dm} \mathrm{HNO}_{3}$ and $7.2 \mathrm{~mol} \mathrm{dm}^{-3} \mathrm{HCl}$.

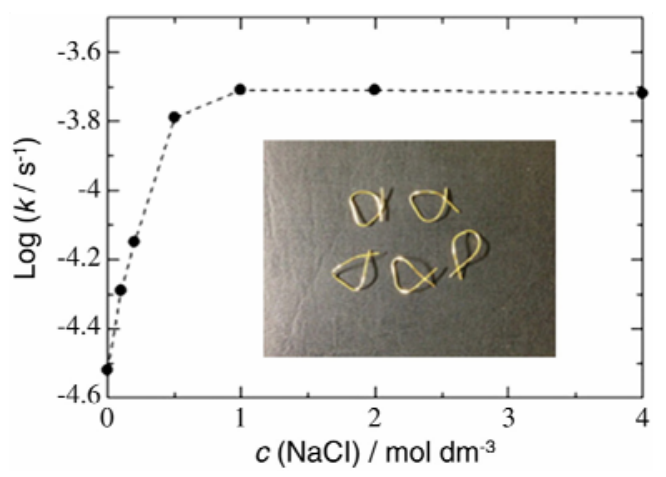

Figure 12. The increase of the dissolution rate constant of gold wire with increasing added $\mathrm{NaCl}$ concentration in the $1.0 \mathrm{~mol} \mathrm{dm}{ }^{-3} \mathrm{HNO}_{3}$ and seawater (a half-concentration) solution at ca. $100{ }^{\circ} \mathrm{C}$. The rate constants have been evaluated by means of spectroscopy.

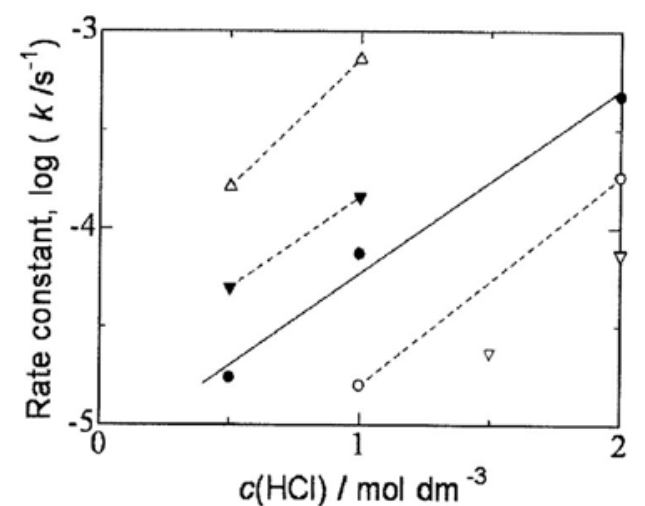

Figure 13. The dissolution rate constants of gold wire $(19.7 \pm 0.5 \mathrm{mg})$ in various concentrations of "dilute aqua regia" at 60 and ca. $100{ }^{\circ} \mathrm{C}:(\nabla) 0.5 \mathrm{~mol} \mathrm{dm}^{-3}$ $\mathrm{HNO}_{3} 60{ }^{\circ} \mathrm{C}$; (०) $1.0 \mathrm{~mol} \mathrm{dm}{ }^{-3} \mathrm{HNO}_{3} 60{ }^{\circ} \mathrm{C}$; (•) $2.0 \mathrm{~mol} \mathrm{dm}{ }^{-3} \mathrm{HNO}_{3} 60{ }^{\circ} \mathrm{C}$; ( $) 0.5 \mathrm{~mol} \mathrm{dm}^{-3} \mathrm{HNO}_{3}$ $100{ }^{\circ} \mathrm{C} ;(\triangle) 1.0 \mathrm{~mol} \mathrm{dm}{ }^{-3} \mathrm{HNO}_{3} 100{ }^{\circ} \mathrm{C}$. The rate constants at 60 and ca. $100{ }^{\circ} \mathrm{C}$ have been evaluated by the mass and spectroscopy, respectively.

The gold dissolution in "dilute aqua regia" has been examined with different $\mathrm{HNO}_{3}$ and $\mathrm{HCl}$ combinations in various concentrations: $0.5,1.0$, and $2.0 \mathrm{~mol} \mathrm{dm}^{-3} \mathrm{HNO}_{3} ; 0.5,1.0,(1.5)$, and $2.0 \mathrm{~mol} \mathrm{dm}^{-3}$ $\mathrm{HCl}$ at $60{ }^{\circ} \mathrm{C}$ (cf. Fig. 13). The [1.0, 1.0] "dilute aqua regia" (of $1.0 \mathrm{~mol} \mathrm{dm}^{-3} \mathrm{HNO}_{3}$ and $1.0 \mathrm{~mol} \mathrm{dm}^{-3}$ $\mathrm{HCl}$ ) gives a dissolution rate constant of $\log \left(\mathrm{k} / \mathrm{s}^{-1}\right)=-4.80$ at $60^{\circ} \mathrm{C}$. With increased $\mathrm{HCl}$ concentration, i.e., of $2.0 \mathrm{~mol} \mathrm{dm}^{-3}$, the rate constant increases: the [1.0, 2.0] "dilute aqua regia" gives -3.74 . The $[2.0,0.5],[2.0,1.0]$, and $[2.0,2.0]$ solutions give a linear relation between $\log \left(\mathrm{k} / \mathrm{s}^{-1}\right)$ and $\mathrm{c}(\mathrm{HCl}) \mathrm{val}-$ ues, to be $-4.76,-4.13$, and -3.33 . Comparing the $[0.5,2.0]$ with the $[2.0,0.5]$ solution, we have noticed that the $[0.5,2.0](-4.13)$ is faster than the $[2.0,0.5](-4.76)$, probably because the ratio between $\mathrm{c}\left(\mathrm{HNO}_{3}\right)$ and $\mathrm{c}(\mathrm{HCl})$ in the $[0.5,2.0]$ may be more favorable than that of the $[2.0,0.5]$ as the "dilute aqua regia" medium. Similarly, the $[1.0,2.0](-3.74)$ is faster than the $[2.0,1.0](-4.13)$ at $60{ }^{\circ} \mathrm{C}$. At $100{ }^{\circ} \mathrm{C}$, the rate constant of "dilute aqua regia" increases remarkably, e.g. the $[1.0,1.0](-3.14)$ at ca. $100{ }^{\circ} \mathrm{C}$ is 46 times faster than the $[1.0,1.0](-4.80)$ at $60^{\circ} \mathrm{C}$. In a very "dilute aqua regia," it takes a very long time to dissolve gold wire (ca. $19.7 \mathrm{mg}$ ) completely: 8 days in both the $[0.5,1.0]$ and the $[1.0,0.5]$ solutions at $60^{\circ} \mathrm{C}$.

\section{Conclusion}

Nitration of phenols was performed by dilute nitric acid $\left(2.0 \mathrm{~mol} \mathrm{dm}^{-3}\right)$ in reversed micelle systems at $35^{\circ} \mathrm{C}$. Even dilute nitric acid in bulk water system, provided it contains salts in high concentrations, can oxidize the $\mathrm{Cl}^{-}$ion to $\mathrm{Cl}_{2}$ as well as $\mathrm{Br}^{-}$to $\mathrm{Br}_{2}$. The nitronium ion $\left(\mathrm{NO}_{2}{ }^{+}\right)$, the active species for nitration or oxidation, can be generated not only in water phase of reversed micelle systems but also in bulk water containing salts in high concentrations. Just as the water structure of nanoscale water droplets in reversed micelle systems is distorted, that of "bulk" aqueous solution can be also distorted by salts in high concentrations and, consequently, "bulk" aqueous solutions should lose the properties of the bulk water.

Although aqueous nitric acid $\left(<2 \mathrm{~mol} \mathrm{dm}^{-3}\right)$ itself exhibits no oxidation ability, it acquires the strong oxidation ability to oxidize $\mathrm{Cl}^{-}$to $\mathrm{Cl}_{2}$ in the presence of chloride salts. The chlorine $\left(\mathrm{Cl}_{2}\right)$ chloride $\left(\mathrm{Cl}^{-}\right)$systems provided by aqueous nitric acid containing enough amounts of chloride salts, have been found to be excellent media for dissolving precious metals, especially, pure gold. In general, the increasing concentrations of chloride salts cause the advanced ability for gold dissolution. At higher temperatures, such as 60 or $100{ }^{\circ} \mathrm{C}$, gold can easily be dissolved into the mixed solution between diluted aqueous $\mathrm{HNO}_{3}$ and $\mathrm{HCl}$, i.e. "dilute aqua regia", which can be applied to prepare a 1000 ppm gold stock solution easily. The "excellent" gold dissolution ability of the mixture of sea- 
water with aqueous nitric acid can be applied to the recovery of gold from waste electronic devices. In electrochemical operation, the Au or Pt electrodes can be dissolved naturally in concentrated halides salt solutions.

The present paper is composed of the rearrangement of J. Mol. Liquids 2011, 163, 161-169 and J. Mol. Liquids 2014, 194, 68-76.

\section{References}

1. Langer, S.; Pemberton, R.S.; Finlayson-Pitts, B.J. J. Phys. Chem. A 1997, 101, 1277.

2. Cotton, F.A.; Wilkinson, G. Advanced Inorganic Chemistry: A Comprehensive Text; 4th Ed; Wiley: New York, 1980; Chap. 6.

3. Petkovic, D.M. J. Chem. Soc. Dalton Trans. 1982, 2425.

4. Hojo, M.; Ueda, T.; Daike, C.; Takezaki, F.; Furuya, Y.; Miyamoto, K.; Narutaki, A.; Kato, R. Bull. Chem. Soc. Jpn. 2006, 79, 1215.

5. Nose, A.; Hojo, M.; Ueda, T. J. Phys. Chem. B 2004, 108, 798.

6. Hojo, M. Pure Appl. Chem. 2008, 80, 1539; and therein.

7. Hojo, M.; Ueda, T.; Ike, M.; Kobayashi, M.; Nakai, H. J. Mol. Liquids 2009, 145, 152.

8. (a) Manege, L. C.; Ueda, T.; Hojo, M. Bull. Chem. Soc. Jpn. 1998, 71, 589. (b) Manege, L. C.; Ueda, T.; Hojo, M.; Fujio, M. J. Chem. Soc. Perkin Trans. 2 1998, 1961. (c) Hojo, M.; Ueda, T.; Inoue, S.; Kawahara, Y. J. Chem. Soc. Perkin Trans. 2 2000, 1735. (d) Hojo, M.; Ueda, T.; Ueno, E.; Hamasaki, T.; Fujimura, D. Bull. Chem. Soc. Jpn. 2006, 79, 751. (e) Hojo, M.; Ueda, T.; Ueno, T.; Hamasaki, T.; Nakano, T. Bull. Chem. Soc. Jpn. 2010, 83, 401. (f) Hojo, M.; Aoki, S. Bull. Chem. Soc. Jpn. 2012, 85, 1023.

9. Reichardt, C.; Che, D.; Heckenkemper, G.; Schaefer, G. Eur. J. Org. Chem. 2001, 2343.

10. Frank, H.S.; Wen, W.-Y.; Discuss. Faraday Soc. 1957, 24, 133.

11. Park, S.; Molianen, D.E.; Fayer, M.D. J. Phys. Chem. B 2008, 112, 5279.

12. Gopalakrishnan, S.; Liu, D.; Allen, H.C.; Kuo, M.; Shultz, M.J. Chem. Rev. 2006, 106, 1155.

13. Kuo, David, M.H.; A.; Kamelamela, N.; White, M.; Shultz, M.J. J. Phys. Chem. C 2007, 111, 8827.

14. Smith, M.B.; March, J. March's Advanced Organic Chemistry Reactions, Mechanisms, and Structure; $6^{\text {th }}$ Ed; Wiley-Interscience: Hoboken, NJ, USA, 2007; p. 689.

15. Smith, M.B.; March, J. March's Advanced Organic Chemistry Reactions, Mechanisms, and Structure; $6^{\text {th }}$ Ed; Wiley-Interscience: Hoboken, NJ, USA, 2007; p. 665.

16. Onori, G.; Santucci, A. J. Phys. Chem. 1993, 97, 5430.

17. Gutmann, V. The Donor-Acceptor Approach to Molecular Interactions; Plenum: New York; 1978.

18. Grove, J. R.; Raphael, L. J. Inorg. Nucl. Chem. 1963, 25, 130.

19. Wright, E.R.; Smith, R.A.; Messick, B.G. In Colorimetric Determination of Nonmetals. Boltz, D.F.; Howell J.A., Eds. Wiley: New York, 1978; Chap. 2, p. 47.

20. Rossi, M.J. Chem. Rev. 2003, 103, 4823.

21. Boltz, D.F.; Holland, W.J.; Howell, J.A. In Colorimetric Determination of Nonmetals. Boltz, D.F.; Howell J.A., Eds. Wiley: New York, 1978; Chap. 4, p. 88.

22. Boughriet, A.; Wartel, M.; Fischer, J.C. J. Electroanal. Chem. 1985, 190, 103.

23. Bard, A.J.; Parsons, R.; Jordan J., Eds. Standard Potentials in Aqueous Solution; Marcel Dekker: New York, 1985.

24. Olah, G.A.; Malhotra, R.; Narang, S.C. Nitration: Methods and Mechanisms; VCH: New York, 1989; p. 192.

25. Bontempelli, G.; Mozzocchin, G.-A.; Magno, F. J. Electroanal. Chem. 1974, 55, 91.

26. Behnke, W.; George, C.; Scheer, V.; Zetzsch, C. J. Geophys. Res. 1997, 102, 3795.

27. Oki, M.; Ohsawa, T.; Tanaka, M.; Chihara H., Eds. Encyclopedic Dictionary of Chemistry; Tokyo Kagaku Dozin: Tokyo, 1989; p. 322 (in Japanese).

28. Moeller, T.; Bailar, J.C. Jr.; Kleinberg, J.; Guss, C.O.; Castellion, M.E.; Metz, C. Chemistry with Inorganic Qualitative Analysis; Academic Press: New York, 1980; p. 670. 
29. Kumar, S.; Varadarajan, R.; Chawla, H.M.; Hundal, G.; Hundal, M.S. Tetrahedron 2004, 60, 1001.

30. Bharadwaj, S.K.; Hussain, S.; Kar, M.; Chaudhuri, M.K. Catalysis Commun. 2008, 9, 919.

31. Bazsa, G. Comments Inorg. Chem. 1986, 5, 57.

32. Scherer, J.R.; Go, M.K.; Kint, S. J. Phys. Chem. 1974, 78, 1304. Irish, D.E.; Brooker, M.H. In Advances in Infrared and Raman Spectroscopy. Clark, R.J.H.; Hester R.E., Eds. Heyden: London, 1976; Vol. 2, Chap. 6, p. 239.

33. Pastorczak, M.; Kozanecki, M.; Ulanski, J. J. Phys. Chem. A 2008, 112, 10705.

34. Gordon, J.E. The Organic Chemistry of Electrolyte Solutions; Wiley: New York, 1975; p. 167.

35. Hindman, J.C. J. Chem. Phys. 1962, 36, 1000.

36. Li, R.; Jiang, Z.; Shi, S.; Yang, H. J. Mol. Struct. 2003, 645, 69.

37. Yonehama, K.; Yoshimura, Y.; Takekiyo, T.; Kanno, H. Bull. Chem. Soc. Jpn. 2009, 82, 563.

38. Abelson, P.H. Science 1986, 233, 141.

39. Beckham, L.J.; Fessler, W.A.; Kise, M. A. Chem. Rev. 1951, 48, 319.

40. Marsden, J.O.; House, C.I. The Chemistry of Gold Extraction; $2^{\text {nd }}$ Ed; Society for Mining, Metallurgy, and Exploration (SME), Inc.: Littleton, Colorado, 2006; p. 233.

41. Marsden, J.O.; House, C.I. The Chemistry of Gold Extraction; $2^{\text {nd }}$ Ed; Society for Mining, Metallurgy, and Exploration (SME), Inc.: Littleton, Colorado, 2006; p. 272.

42. (a) Debye, P.; Hückel, E. Phys. Z. 1923, 24, 185, 305. (b) Fraenkel, D. J. Phys. Chem. B, 2011, 115, 14634.

43. Pitzer, K.S. Activity Coefficients in Electrolyte Solutions; 2nd Ed; CRC: Boca Raton, Florida, 1991.

44. Nakahara, M. Dictionary of Inorganic Compounds and Complexes; Kodansha Scientific: Tokyo, 1997 (in Japanese).

45. Jones, P.G.; Schelbach, R.; Schwarzmann, E. Z. Naturforsch. B 1987, 42, 522.

46. Roehl, C.M.; Orlando, J.J.; Calvert, J.G. J. Photochem. Photobiol. A: Chem. 1992, 69, 1.

47. Whitfield, M. Sea Water as an Electrolyte Solution. In Chemical Oceanography. Riley, J. P.; Skirrow G., Eds.; Vol. 1; $2^{\text {nd }}$ Ed; Academic Press: London, 1975; Chap. 2.

48. Holland, H.D. The Chemistry of the Atmosphere and Ocean; Wiley: New York, 1978; Chap. 5.

49. http://en.wikipedia.org/wiki/Seawater.

50. Sayd, S. Hydrometallurgy 2012, 115-116, 30.

51. Weast, R. C. Handbook of Chemistry and Physics; $70^{\text {th }}$ Ed; CRC: Boca Raton, Florida, 1989; D-130.

Надіслано до редакиії 17 жовтня 2019 р.

М. Ходжо. Механизм повышенной окисляющей способности разбавленной азотной кислоты и растворение металлического золота в азотной кислоте, разбавленной морской водой.

Департамент химии, фракультет науки, Университет г. Кочи, Кочи, 780-8520, Япония

Обнаружено, что разбавленная азотная кислота в обращённых мицеллах может окислять ион $\mathrm{Br}^{-}$до $\mathrm{Br}_{2}$, и предложено использовать нитроний, $\mathrm{NO}_{2}{ }^{+}$, как активный реагент в окислительном процессе. Нитрование фенола разбавленной азотной кислотой в водной дисперсной фазе обращённой мицеллярной системы $\mathrm{CHCl}_{3} /$ хлорид цетилтриметиламмония/ $\mathrm{H}_{2} \mathrm{O}\left(2.0\right.$ моль дм ${ }^{-3} \mathrm{HNO}_{3}$ при содержании воды $1.0 \%$ (v/v), проведённое при $35^{\circ} \mathrm{C}$, привело к образованию 2- и 4-нитрофенолов. В водном растворе $\mathrm{HNO}_{3} \mathrm{C}$ концентрацией 2.0 моль дм ${ }^{-3}$ в присутствии 4.0 моль дм $^{-3} \mathrm{LiCl}$ и небольшого количества $\mathrm{LiBr}$ как источника бромида $\mathrm{mpaнc-}$ 1,4-дибром-2-бутен успешно бромируется до 1,2,3,4-тетрабромбутана. Этот результат является хорошим подтверждением возможности окисления иона $\mathrm{Br}^{-}$до $\mathrm{Br}_{2}$ в разбавленной до 2.0 моль дм ${ }^{-3}$ азотной кислоте в присутствии концентрированных солей. Для серии хлоридов эффект катиона возрастает в ряду: $\mathrm{Et}_{4} \mathrm{~N}^{+}<<$ $\mathrm{Na}^{+}<\mathrm{Li}^{+}<\mathrm{Ca}^{2+}<\mathrm{Mg}^{2+}$. Наблюдалось даже выделение $\mathrm{Cl}_{2}$ из раствора $\mathrm{HNO}_{3}$ с концентрацией $<2.0$ моль дм $^{-3}$, содержащего высокие концентрации $\mathrm{LiCl}, \mathrm{MgCl}_{2}$ и $\mathrm{CaCl}_{2}$, а также $\mathrm{AlCl}_{3}$. Показано растворение благородных металлов (Au, Pt, and Pd) и особенно золота в 0.1 - 2 моль дм ${ }^{-3} \mathrm{HNO}_{3}$ в присутствии хлоридов щелочных и щелочноземельных металлов, а также хлорида алюминия. Время полного растворения пластины из металлического золота массой $20 \pm 2$ мг и толщиной 0.1 мм в 2.0 моль дм ${ }^{-3} \mathrm{HNO}_{3}$ в присутствии 1.0 моль дм ${ }^{-3} \mathrm{AlCl}_{3}$ заметно сокращается при повышении температуры от 15 до $80^{\circ} \mathrm{C}$. Скорость растворения кусочка золотой проволоки массой $19.7 \pm 0.5$ мг в 20 мл раствора $\mathrm{HNO}_{3}$ концентрации 2.0 моль дм $^{-3}$ в 
присутствии хлоридов металлов в целом возрастает при увеличении концентрации солей при 40 и $60{ }^{\circ} \mathrm{C}$. Золото может растворяться при концентрациях $\mathrm{HNO}_{3}$ и $\mathrm{HCl}$ менее 1.0 моль дм"- , т.е. в "разбавленной царской водке“. Нами достигнуто полное растворение пяти кусочков золотой проволоки суммарной массой 0.10 г в 100 мл смеси морской воды с 2.0 моль дм ${ }^{-3} \mathrm{HNO}_{3}$ в соотношении 1: 1 при $\approx 100^{\circ} \mathrm{C}$.

Ключевые слова: нитроний ион, хлорид цетилтриметиламмония, выделение хлора, окисление бромида, солевой эффект, структура объёмной воды, разбавленная царская водка, тетрахлораурат, концентрированная соль, Рамановский спектр.

М. Ходжо. Механізм підвищеної окислюючої здатності розведеної нітратної кислоти і розчинення металевого золота в нітратній кислоті, розведеній морською водою.

Департамент хімії, фракультет науки, Університет м. Кочі, Кочі, 780-8520, Японія

Знайдено, що розведена нітратна кислота в обернених міцелах може окислювати іон $\mathrm{Br}^{-}$до $\mathrm{Br}_{2}$, та запропоновано використовувати нітроній, $\mathrm{NO}_{2}{ }^{+}$, як активний реагент в окислювальному процесі. Нітрування фенолу розведеною нітратною кислотою в водній дисперсній фазі оберненої міцелярної системи $\mathrm{CHCl}_{3} /$ хлорид цетилтриметиламонію/ $\mathrm{H}_{2} \mathrm{O}\left(2.0\right.$ моль дм ${ }^{-3} \mathrm{HNO}_{3}$ при вмісті воді $1.0 \%$ (v/v), проведене при $35^{\circ} \mathrm{C}$, привело до створення 2- та 4-нітрофенолів. У водному розчині $\mathrm{HNO}_{3} 3$ концентрацією 2.0 моль дм $^{-3}$ в присутності 4.0 моль дм ${ }^{-3} \mathrm{LiCl}$ і невеликої кількості $\mathrm{LiBr}$ як джерела броміду транс-1,4-дибром-2-бутен успішно хромується до 1,2,3,4-тетрабромбутану. Цей результат є добрим підтвердженням можливості окислення іону $\mathrm{Br}^{-}$до $\mathrm{Br}_{2}$ в розведеній до 2.0 моль дм ${ }^{-3}$ нітратній кислоті у присутності концентрованих солей. Для серії хлоридів ефект катіону зростає у послідовності: $\mathrm{Et}_{4} \mathrm{~N}^{+}<<\mathrm{Na}^{+}<\mathrm{Li}^{+}<\mathrm{Ca}^{2+}<\mathrm{Mg}^{2+}$. Спостерігалося також виділення $\mathrm{Cl}_{2}$ з розчину $\mathrm{HNO}_{3}$ з концентрацією $<2.0$ моль дм ${ }^{-3}$, який містить високі концентрації $\mathrm{LiCl}$, $\mathrm{MgCl}_{2}$ и $\mathrm{CaCl}_{2}$, а також $\mathrm{AlCl}_{3}$. Показано повне розчинення благородних металів ( $\mathrm{Au}, \mathrm{Pt}$, and $\mathrm{Pd}$ ) i особливо золота в 0.1 - 2 моль дм ${ }^{-3} \mathrm{HNO}_{3}$ в присутності хлоридів лужних та лужноземельних металів, а також хлориду алюминию. Час повного розчинення пластини з металевого золота масою $20 \pm 2$ мг і товщиною 0.1 мм в 2.0 моль дм $^{-3} \mathrm{HNO}_{3}$ в присутності 1.0 моль дм$^{-3} \mathrm{AlCl}_{3}$ помітно зменшується при підвищенні температури від от 15 до $80{ }^{\circ} \mathrm{C}$. Швидкість розчинення шматочка золотого дроту масою $19.7 \pm 0.5$ мг в 20 мл розчину $\mathrm{HNO}_{3} 3$ концентрацією 2.0 моль дм ${ }^{-3}$ в присутності хлоридів металів в цілому зростає при підвищенні концентрації солей при 40 і $60{ }^{\circ} \mathrm{C}$. Золото може розчинятися при концентраціях $\mathrm{HNO}_{3}$ і $\mathrm{HCl}$ менших ніж 1.0 моль дм $^{-3}$, тобто в «розведеній царській водці». Нами досягнуте повне розчинення п'яти шматочків золотого дроту сумарною масою 0.10 г в 100 мл суміші морської води з 2.0 моль дм ${ }^{-3} \mathrm{HNO}_{3}$ у співвідношенні $1: 1$ при $\approx 100^{\circ} \mathrm{C}$.

Ключові слова: нітроній іон, хлорид цетилтриметиламонію, виділення хлору, окислення броміду, сольовий ефект, структура об'ємної води, розведена царська водка, тетрахлораурат, концентрована сіль, Рамановський спектр.

Kharkiv University Bulletin. Chemical Series. Issue 33 (56), 2019 